Saudi Journal of Biomedical Research

Abbreviated Key Title: Saudi J Biomed Res ISSN 2518-3214 (Print) |ISSN 2518-3222 (Online)

\title{
Investigation of Prevention, Protection and Treatment of Ritonavir Effectiveness on Coronavirus Disease-2019 (COVID-19) Infection Using Fourier Transform Raman (FT-Raman) Biospectroscopy
}

\author{
Alireza Heidari*
}

Faculty of Chemistry, California South University, 14731 Comet St. Irvine, CA 92604, USA

American International Standards Institute, Irvine, CA 3800, USA

\section{DOI: $10.36348 /$ sjbr.2020.v05i07.005}

| Received: 03.06.2020 | Accepted: 11.06.2020 | Published: 30.07.2020

*Corresponding author: Alireza Heidari

\section{Abstract}

Ritonavir is an antiretroviral of the protease inhibitor class. It is used against HIV infections as a fixed-dose combination with another protease inhibitor, ritonavir (lopinavir/ritonavir). In the current research, the stimulated FT-Raman biospectroscopy of liquid sample of Ritonavir was investigated. The stimulated FT-Raman diffractions emitted through focusing the second harmonic laser beam Nd:YAG into the sample were recorded by Echelle spectrometer and ICCD detector. Increasing the energy of laser beam from $2.6(\mathrm{~mJ})$ to $16(\mathrm{~mJ})$ was led to increase in stimulated FT-Raman signal but after breakdown threshold of liquid sample, more increasing of energy was led to decrease in stimulate FT-Raman signals and for energies higher than $20(\mathrm{~mJ})$, they were disappeared.

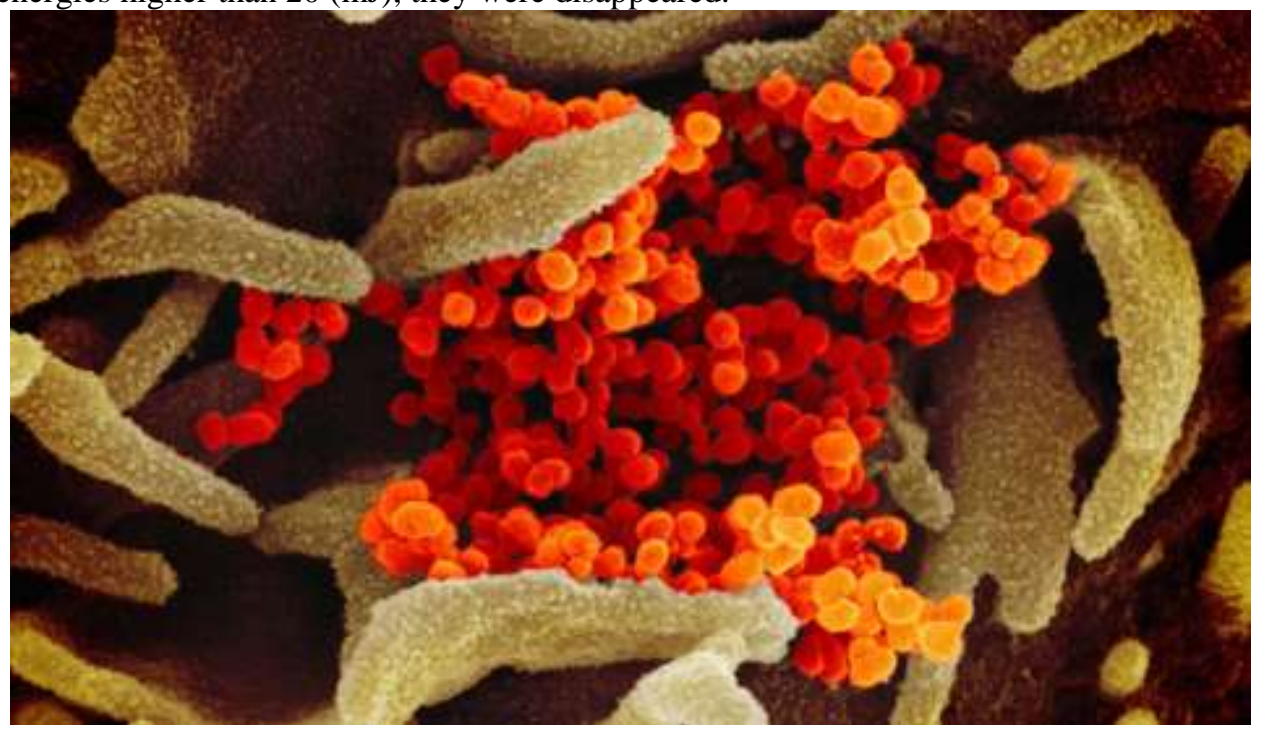

Ritonavir Effectiveness on Coronavirus Disease-2019 (COVID-19) Infection

Keywords: FT-Raman Biospectroscopy, Stimulated FT-Raman Biospectroscopy, Ritonavir, Breakdown, Coronavirus Disease-2019, COVID-19, Infection, Protective and Therapeutic Effect, Potent Drug.

\begin{abstract}
Copyright @ 2020: This is an open-access article distributed under the terms of the Creative Commons Attribution license which permits unrestricted use, distribution, and reproduction in any medium for non-commercial use (NonCommercial, or CC-BY-NC) provided the original author and source are credited.
\end{abstract}

\section{INTRODUCTION}

FT-Raman biospectroscopy is a vibration biospectroscopy based on the influence of FT-Raman [1-47]. The influence of FT-Raman is elastically diffracting the electromagnetic ray due to rotational and vibrational transitions in molecules and its characteristic is changing the energy of diffracted beam photons compared to incident beam [48-95]. The difference between wavelength of incident beam light and diffracted light is related to molecular vibrations and is considered as exclusive "chemical finger print" of sample and can be used in identification of molecular compounds on a surface, into a liquid or into the air [96-142]. 
The stimulated FT-Raman diffraction is a non-linear effect [143-189]. If the pumping intensity exceeds the threshold of this effect, it observes [190237]. The pumping threshold limit for stimulated FTRaman depends on FT-Raman active material [238285]. Regarding the spectral characteristics, stimulated FT-Raman can be distinguished from normal FTRaman [286-333]. While the intensity of FT-Raman bands are several times smaller than pumping laser intensity in normal FT-Raman, the intensity of FTRaman bands in stimulated FT-Raman can be similar to laser intensity and for most materials, only strongest FT-Raman bands of material are intensified and are dominant in the recorded spectrum of material [334377].

In the current research, the stimulated FTRaman spectrum are obtained through pumping the second harmonic beam laser $\mathrm{Nd}: \mathrm{YAG}$ and it is performed by a spectrometer and detector. The resulted spectra and their characteristics are investigated here.

\section{Experimental Arrangement}

The experimental arrangement used in the current study is schematically shown in Figure (1). The first harmonic bicolor mirror reflects 1064 (nm) but passes the second harmonic one. As a result, the first harmonic removes from laser beam. The second harmonic laser Nd: YAG with wavelength of $532(\mathrm{~nm})$ and pulse width of 8 (ns) interacts with the sample after passing through bicolor mirror and lens with focal length of $3.5(\mathrm{~cm})$. The resulted emissions from this interaction filter by an optical system consisting some lens and optical fiber conducts to Eschelle spectrometer. The necessary time range for collecting spectra and its start time in ICCD detector controls by delayer device. Optical emissions of sample collects and intensifies from the striking moment of laser to sample until 5 (ms) after that moment. Test was repeated five times for each energy level for laser energy from $2.4(\mathrm{~mJ})$ to $29(\mathrm{~mJ})$.

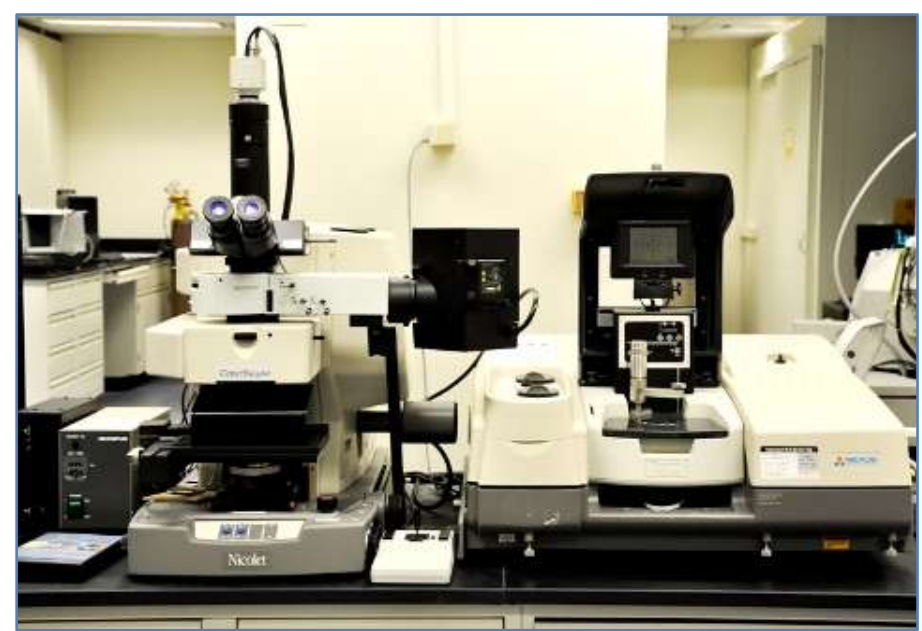

Fig-1: Schematic of stimulated FT-Raman biospectroscopy test arrangement

\section{RESULTS AND DISCUSSION}

Figure (2) shows the normal and stimulated FT-Raman spectra. Normal FT-Raman spectrum can be obtained when laser beam is not focused on the sample. When laser beam focuses on sample using a lens, non-linear effects stimulate and stronger bands of FT-Raman spectrum intensify up to some levels of laser intensity.

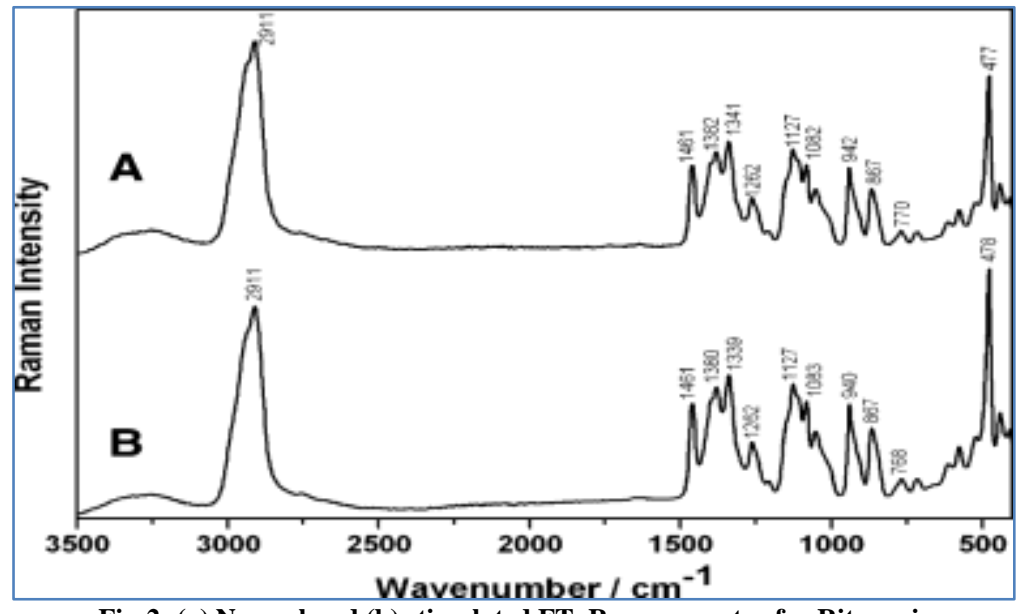

Fig-2: (a) Normal and (b) stimulated FT-Raman spectra for Ritonavir 
By increasing the energy of laser beam, the intensity of main bands of $1380\left(\mathrm{~cm}^{-1}\right)$ and $1461\left(\mathrm{~cm}^{-1}\right)$ also are increased and for energy levels higher than 8 $(\mathrm{mJ})$, anti-Stokes FT-Raman band corresponding to $1380\left(\mathrm{~cm}^{-1}\right)$ intensifies in the spectrum and can be observed at left hand side of laser line in FT-Raman shift of $-1380\left(\mathrm{~cm}^{-1}\right)$. Recording the anti-Stokes band necessitates the occupation of corresponding vibration level through diffraction of Stokes FT-Raman (Table $1)$.
By more increasing the energy level higher than $16(\mathrm{~mJ})$, all four graphs of Figure (3) shows reduction in intensity. The reason for this reduction is creation of spark in the Ritonavir liquid due to increase in energy of laser more than the breakdown threshold of liquid. As a result of this spark, which creates in the center of liquid, laser beam absorbs by liquid and some part of it diffracts and only this part plays a role in creation of stimulated FT-Raman. By increasing the energy, beam has higher contribution in making the spark and the diffracted emission which reaches to detector decreases.

Table-1: FT-Raman modes for Ritonavir.

\begin{tabular}{|l|c|c|}
\hline & FT-Raman Shift $\left(\mathbf{c m}^{-\mathbf{1}}\right)$ & FT-Raman Mode \\
\hline $\mathbf{1}$ & $940\left(\mathrm{~cm}^{-1}\right)$ & $\mathrm{C}-\mathrm{H}$ Stretch \\
\hline $\mathbf{2}$ & $1127\left(\mathrm{~cm}^{-1}\right)$ & $\mathrm{CH}_{2}$ Rocking \\
\hline $\mathbf{4}$ & $1339\left(\mathrm{~cm}^{-1}\right)$ & $\mathrm{CH}_{2}$ Wagging \\
\hline $\mathbf{5}$ & $1380\left(\mathrm{~cm}^{-1}\right)$ & $\mathrm{CH}_{2}$ Symmetric Stretch \\
\hline $\mathbf{7}$ & $1461\left(\mathrm{~cm}^{-1}\right)$ & $\mathrm{C}-\mathrm{H}$ Asymmetric Stretch \\
\hline
\end{tabular}
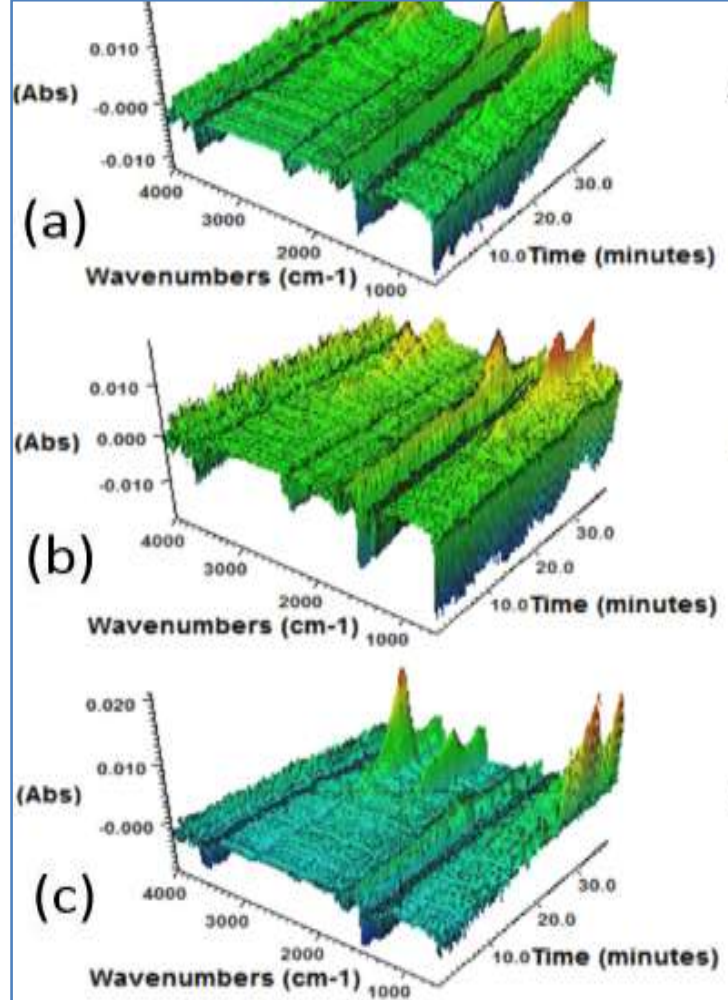

Absorbance (Abs)

(d)

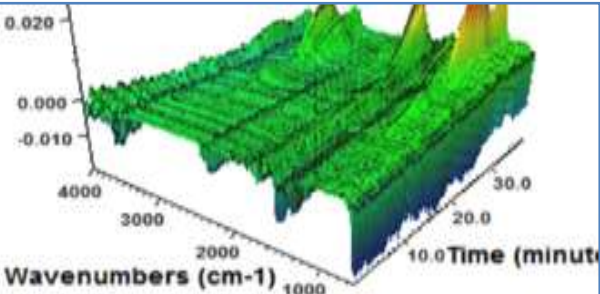

Absorbance (Abs)

(e)

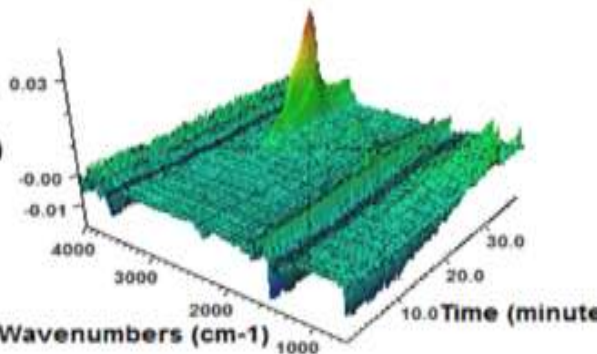

Absorbance (Abs)

(f)

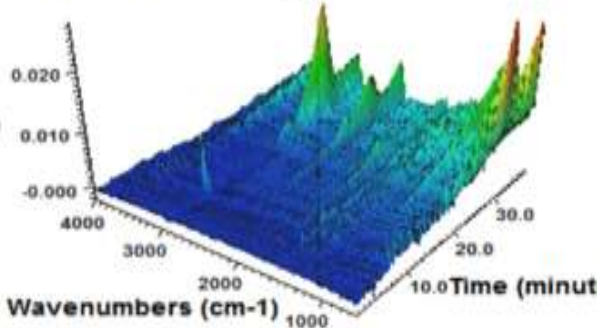

Fig-3: Peak intensity (a) band $940\left(\mathrm{~cm}^{-1}\right)$, (b) band $1127\left(\mathrm{~cm}^{-1}\right)$, (c) band $1339\left(\mathrm{~cm}^{-1}\right)$, (d) band $1380\left(\mathrm{~cm}^{-1}\right)$, (e) band $1461\left(\mathrm{~cm}^{-1}\right)$ and (f) band $1380\left(\mathrm{~cm}^{-1}\right)$ based on increase in energy level of beam focused on the liquid

\section{CONCLUSIONS AND SUMMARY}

The stimulated FT-Raman biospectroscopy test was performed for liquid sample of Ritonavir. The main band at $1380\left(\mathrm{~cm}^{-1}\right)$ shows an intensity level comparable to pumping laser intensity. The intensity of stimulated FT-Raman spectrum at $16(\mathrm{~mJ})$ energy level is the highest intensity in this test and more increasing the energy level reduces the intensity of spectrum. The reason for this reduction is creation of spark in the Ritonavir liquid due to increase in energy of laser more than the breakdown threshold of Ritonavir.

\section{REFERENCES}

1. Heidari, A., \& Brown, C. (2015). Study of composition and morphology of cadmium oxide 
(CdO) nanoparticles for eliminating cancer cells. Journal of Nanomedicine Research, 2(5), 20.

2. Heidari, A., \& Brown, C. (2015). Study of surface morphological, phytochemical and structural characteristics of rhodium (III) oxide (Rh2O3) nanoparticles. International Journal of Pharmacology, Phytochemistry and Ethnomedicine, 1(1), 15-19.

3. Heidari, A. (2016). An experimental biospectroscopic study on seminal plasma in determination of semen quality for evaluation of male infertility. Int J Adv Technol, 7(2), 1-2.

4. Heidari, A. (2016). Extraction and preconcentration of n-tolyl-sulfonyl-phosphoramid-saeuredichlorid as an anti-cancer drug from plants: a pharmacognosy study. J Pharmacogn Nat Prod, 2(2), e103.

5. Heidari, A. (2016). A thermodynamic study on hydration and dehydration of DNA and RNAamphiphile complexes. J Bioeng Biomed Sci S, 6 .

6. Heidari, A. (2016). Computational studies on molecular structures and carbonyl and ketene groups' effects of singlet and triplet energies of azidoketene $\mathrm{O}=\mathrm{C}=\mathrm{CH}-\mathrm{NNN}$ and isocyanatoketene $\mathrm{O}=\mathrm{C}=\mathrm{CH}-\mathrm{N}=\mathrm{C}=\mathrm{O} . J$ Appl Computat Math, 5(1), e142.

7. Heidari, A. (2016). Study of irradiations to enhance the induces the dissociation of hydrogen bonds between peptide chains and transition from helix structure to random coil structure using ATRFTIR, raman and 1HNMR spectroscopies. $J$ Biomol Res Ther, 5(2), e146.

8. Heidari, A. (2016). Future prospects of point fluorescence spectroscopy, fluorescence imaging and fluorescence endoscopy in photodynamic therapy (PDT) for cancer cells. $J$ Bioanal Biomed, 8(2), e135.

9. Heidari, A. (2016). A bio-spectroscopic study of DNA density and color role as determining factor for absorbed irradiation in cancer cells. Adv Cancer Prev, 1(2), e102.

10. Heidari, A. (2016). Manufacturing Process of Solar Cells Using Cadmium Oxide $(\mathrm{CdO})$ and Rhodium (III) Oxide (Rh2O3) Nanoparticles. J Biotechnol Biomater, 6(2), e125.

11. Heidari, A. (2016). A Novel Experimental and Computational Approach to Photobiosimulation of Telomeric DNA/RNA: A Biospectroscopic and Photobiological Study.J Res Development,4(1), 1000144.

12. Heidari, A. (2016). Biochemical and pharmacodynamical study of microporous molecularly imprinted polymer selective for vancomycin, teicoplanin, oritavancin, telavancin and dalbavancin binding. Biochem Physiol, 5(2), e146.

13. Heidari, A. (2016). Anti-Cancer Effect of UV Irradiation at Presence of Cadmium Oxide $(\mathrm{CdO})$ Nanoparticles on DNA of Cancer Cells: A
Photodynamic Therapy Study. Arch Cancer Res, 4(1), 61.

14. Heidari, A. (2016). Biospectroscopic Study on Multi-Component Reactions (MCRs) in Two AType and B-Type Conformations of Nucleic Acids to Determine Ligand Binding Modes, Binding Constant and Stability of Nucleic Acids in Cadmium Oxide (CdO) Nanoparticles-Nucleic Acids Complexes as Anti-Cancer Drugs. Arch Cancer Res, 4(2), 65.

15. Heidari, A. (2016). Simulation of temperature distribution of DNA/RNA of human cancer cells using time-dependent bio-heat equation and $\mathrm{Nd}$ : YAG lasers. Arch Cancer Res, 4(2), 69.

16. Heidari, A. (2016). Quantitative structure-activity relationship (QSAR) approximation for cadmium oxide (CdO) and rhodium (III) oxide (Rh2O3) nanoparticles as anti-cancer drugs for the catalytic formation of proviral DNA from viral RNA using multiple linear and non-linear correlation approach. Ann Clin Lab Res, 4(1), 76.

17. Heidari, A. (2016). Biomedical study of cancer cells DNA therapy using laser irradiations at presence of intelligent nanoparticles. J Biomedical Sci, 5(2), 9.

18. Heidari, A. (2016). Measurement the amount of vitamin D2 (ergocalciferol), vitamin D3 (cholecalciferol) and absorbable calcium $(\mathrm{Ca} 2+)$, iron $(\mathrm{II})(\mathrm{Fe} 2+)$, magnesium $(\mathrm{Mg} 2+)$, phosphate (PO4-) and zinc ( $\mathrm{Zn} 2+)$ in apricot using highperformance liquid chromatography (HPLC) and spectroscopic techniques. J Biom Biostat, 7(2), 292.

19. Heidari, A. (2016). Spectroscopy and Quantum Mechanics of the Helium Dimer $(\mathrm{He} 2+)$, Neon Dimer (Ne2+), Argon Dimer (Ar2+), Krypton Dimer $(\mathrm{Kr} 2+)$, Xenon Dimer (Xe2+), Radon Dimer (Rn2+) and Ununoctium Dimer (Uuo2+) Molecular Cations", Chem Sci J 7: e112. Pubmed| Crossref| Others.

20. Heidari, A. (2016). Human toxicity photodynamic therapy studies on DNA/RNA complexes as a promising new sensitizer for the treatment of malignant tumors using bio-spectroscopic techniques. J Drug Metab Toxicol, 7(2), e129.

21. Heidari, A. (2016). Novel and stable modifications of intelligent cadmium oxide $(\mathrm{CdO})$ nanoparticles as anti-cancer drug in formation of nucleic acids complexes for human cancer cells' treatment. Biochem Pharmacol (Los Angel), 5(3), 207.

22. Heidari, A. (2016). A combined computational and QM/MM molecular dynamics study on boron nitride nanotubes (BNNTs), amorphous boron nitride nanotubes (a-BNNTs) and hexagonal boron nitride nanotubes (h-BNNTs) as hydrogen storage. Struct Chem Crystallogr Commun, 2(1), 7.

23. A. Heidari, "Pharmaceutical and Analytical Chemistry Study of Cadmium Oxide (CdO) Nanoparticles Synthesis Methods and Properties as 
Anti-Cancer Drug and its Effect on Human Cancer Cells", Pharm Anal Chem Open Access 2: 113, 2016.

24. Heidari, A. (2016). A Chemotherapeutic and Biospectroscopic Investigation of the Interaction of Double-Standard DNA/RNA-Binding Molecules with Cadmium Oxide (CdO) and Rhodium (III) Oxide (Rh2O3) Nanoparticles as Anti-Cancer Drugs for Cancer Cells' Treatment. Chemo Open Access, 5(2), e129.

25. Heidari, A. (2016). A Chemotherapeutic and Biospectroscopic Investigation of the Interaction of Double-Standard DNA/RNA-Binding Molecules with Cadmium Oxide (CdO) and Rhodium (III) Oxide (Rh2O3) Nanoparticles as Anti-Cancer Drugs for Cancer Cells' Treatment. Chemo Open Access, 5(2), e129.

26. Heidari, A. (2016). Determination of ratio and stability constant of DNA/RNA in human cancer cells and Cadmium Oxide $(\mathrm{CdO})$ nanoparticles complexes using analytical electrochemical and spectroscopic techniques. Insights Anal Electrochem, 2(1), 14.

27. Heidari, A. (2016). Discriminate between antibacterial and non-antibacterial drugs artificial neutral networks of a multilayer perceptron (MLP) type using a set of topological descriptors. J Heavy Met Toxicity Dis, 1(2), 28.

28. A. Heidari, "Combined Theoretical and Computational Study of the Belousov-Zhabotinsky Chaotic Reaction and Curtius Rearrangement for Synthesis of Mechlorethamine, Cisplatin, Streptozotocin, Cyclophosphamide, Melphalan, Busulphan and BCNU as Anti-Cancer Drugs", Insights Med Phys. 1: 2, 2016.

29. Heidari, A. (2016). A translational biomedical approach to structural arrangement of amino acids' complexes: a combined theoretical and computational study. Transl Biomed, 7(2), 72.

30. Heidari, A. (2016). Ab initio and density functional theory (DFT) studies of dynamic NMR shielding tensors and vibrational frequencies of DNA/RNA and Cadmium Oxide $(\mathrm{CdO})$ nanoparticles complexes in human cancer cells. J Nanomedine Biotherapeutic Discov, 6(2), e144.

31. Heidari, A. (2016). Molecular Dynamics and Monte-Carlo Simulations for Replacement Sugars in Insulin Resistance, Obesity, LDL Cholesterol, Triglycerides, Metabolic Syndrome, Type 2 Diabetes and Cardiovascular Disease: A Glycobiological Study. J Glycobiol, 5(1), e111.

32. Heidari, A. (2016). Synthesis and Study of 5[(Phenylsulfonyl) Amino]-1, 3, 4-Thiadiazole-2Sulfonamide as Potential Anti-Pertussis Drug Using Chromatography and Spectroscopy Techniques. Transl Med (Sunnyvale), 6(3), e137.

33. Heidari, A. Nitrogen, Oxygen, Phosphorus and Sulphur Heterocyclic Anti-Cancer Nano Drugs Separation in the Supercritical Fluid of Ozone (O3) Using Soave-Redlich-Kwong (SRK) and Pang-
Robinson (PR) Equations. Electronic J Biol. 2016; 12: 4. Ref. Pubmed | Crossref $\mid$ Others.

34. Heidari, A. (2016). An analytical and computational infrared spectroscopic review of vibrational modes in nucleic acids. Austin J Anal Pharm Chem, 3(1), 1058.

35. Heidari, A., \& Brown, C. (2016). Phase, composition and morphology study and analysis of Os-Pd/HfC nanocomposites. Nano Res Appl, 2(1).

36. Heidari, A., \& Brown, C. (2016). Vibrational spectroscopic study of intensities and shifts of symmetric vibration modes of ozone diluted by cumene. International Journal of Advanced Chemistry, 4(1), 5-9.

37. Heidari, A. (2016). Study of the role of anti-cancer molecules with different sizes for decreasing corresponding bulk tumor multiple organs or tissues. Arch Can Res, 4(2), 38.

38. Heidari, A. (2016). Genomics and proteomics studies of zolpidem, necopidem, alpidem, saripidem, miroprofen, zolimidine, olprinone and abafungin as anti-tumor, peptide antibiotics, antiviral and central nervous system (CNS) drugs. $J$ Data Mining Genomics \& Proteomics, 7(3), e125.

39. Heidari, A. (2016). Pharmacogenomics and pharmacoproteomics studies of phosphodiesterase5 (PDE5) inhibitors and paclitaxel albuminstabilized nanoparticles as sandwiched anti-cancer nano drugs between two DNA/RNA molecules of human cancer cells. $J$ Pharmacogenomics Pharmacoproteomics, 7(2), e153.

40. Heidari, A. (2016). Biotranslational Medical and Biospectroscopic Studies of Cadmium Oxide (CdO) Nanoparticles-DNA/RNA Straight and Cycle Chain Complexes as Potent Anti-Viral, Anti-Tumor and Anti-Microbial Drugs: A Clinical Approach. Transl Biomed, 7(2), 76.

41. Heidari, A. (2016). A Comparative Study on Simultaneous Determination and Separation of Adsorbed Cadmium Oxide (CdO) Nanoparticles on DNA/RNA of Human Cancer Cells Using Biospectroscopic Techniques and Dielectrophoresis (DEP) Method. Arch Can Res, 4(2), 42.

42. Heidari, A. (2016). Cheminformatics and system chemistry of cisplatin, carboplatin, nedaplatin, oxaliplatin, heptaplatin and lobaplatin as anticancer nano drugs: a combined computational and experimental study. J Inform Data Min, 1(3), 24721956.

43. Heidari, A. (2016). Linear and Non-Linear Quantitative Structure-Anti-Cancer-Activity Relationship (QSACAR) Study of Hydrous Ruthenium (IV) Oxide (RuO2) Nanoparticles as Non-Nucleoside Reverse Transcriptase Inhibitors (NNRTIs) and Anti-Cancer Nano Drugs. J Integr Oncol, 5(3), e110.

44. Heidari, A. (2016). Synthesis, Characterization and Biospectroscopic Studies of Cadmium Oxide (CdO) Nanoparticles-Nucleic Acids Complexes 
Absence of Soluble Polymer as a Protective Agent Using Nucleic Acids Condensation and Solution Reduction Method. J Nanosci Curr Res 1: e101. doi: $10.4172 / 2572-0813.1000$ e101 Page 2 of 2 Volume 1• Issue 1・1000e101 J Res Development, an open access journal ISSN: 2311-3278 of tannic acid-modified silver nanoparticles in keratinocytes: potential fo $\mathrm{r}$ immunomodulatory applications. Toxicol in Vitro, 35, 43-54.

45. Heidari, A. (2016). Coplanarity and collinearity of 4'-dinonyl-2, 2'-bithiazole in one domain of bleomycin and pingyangmycin to be responsible for binding of cadmium oxide $(\mathrm{CdO})$ nanoparticles to DNA/RNA bidentate ligands as anti-tumor nano drug. Int J Drug Dev \& Res, 8(3), 007-008.

46. Heidari, A. (2016). A pharmacovigilance study on linear and non-linear quantitative structure (chromatographic) retention relationships (QSRR) models for the prediction of retention time of anticancer nano drugs under synchrotron radiations. $J$ Pharmacovigil, 4(4), e161.

47. Heidari, A. (2016). Nanotechnology in preparation of semipermeable polymers. J Adv Chem Eng, 6(2), 157.

48. Heidari, A. (2016). A gastrointestinal study on linear and non-linear quantitative structure (chromatographic) retention relationships (QSRR) models for analysis 5-aminosalicylates nano particles as digestive system nano drugs under synchrotron radiations. J Gastrointest Dig Syst, 6(4), e119.

49. Heidari, A. (2016). DNA/RNA fragmentation and cytolysis in human cancer cells treated with diphthamide nano particles derivatives. Biomedical Data Mining, 5(1), e102.

50. Heidari, A. (2016). A successful strategy for the prediction of solubility in the construction of quantitative structure-activity relationship (QSAR) and quantitative structure-property relationship (QSPR) under synchrotron radiations using genetic function approximation (GFA) algorithm. $\mathrm{J} \mathrm{Mol}$ Biol Biotechnol, 1(1), 1.

51. Heidari, A. (2016). Computational study on molecular structures of C20, C60, C240, C540, C960, C2160 and C3840 fullerene nano molecules under synchrotron radiations using fuzzy logic. $J$ Material Sci Eng, 5(282), 2169-0022.

52. Heidari, A. (2016). Graph theoretical analysis of zigzag polyhexamethylene biguanide, polyhexamethylene adipamide, polyhexamethylene biguanide gauze and polyhexamethylene biguanide hydrochloride (PHMB) boron nitride nanotubes (BNNTs), amorphous boron nitride nanotubes (aBNNTs) and hexagonal boron nitride nanotubes (h-BNNTs). J Appl Computat Math, 5(5), e143.

53. Heidari, A. (2016). The impact of high resolution imaging on diagnosis. Int $J$ Clin Med Imaging, 3(6), 1000e101.

54. Heidari, A. (2016). A Comparative Study of Conformational Behavior of Isotretinoin (13-Cis
Retinoic Acid) and Tretinoin (All-Trans Retinoic Acid (ATRA)) Nano Particles as Anti-Cancer Nano Drugs under Synchrotron Radiations Using Hartree-Fock (HF) and Density Functional Theory (DFT) Methods. Insights in Biomed, 1(2), 8.

55. Heidari, A. (2016). Advances in logic, operations and computational mathematics. J Appl Computat Math, 5(5), e144.

56. Heidari, A. (2016). Mathematical equations in predicting physical behavior.J Appl Computat Math, 5(5), e145.

57. Heidari, A. (2016). Chemotherapy a last resort for cancer treatment. Chemo Open Access, 5(4), e130.

58. Heidari, A. (2016). Separation and preconcentration of metal cations-DNA/RNA chelates using molecular beam mass spectrometry with tunable vacuum ultraviolet (VUV) synchrotron radiation and various analytical methods. Mass Spectrom Purif Tech, 2(1), e101.

59. Heidari, A. (2016). Yoctosecond quantitative structure-activity relationship (QSAR) and quantitative structure-property relationship (QSPR) under synchrotron radiations studies for prediction of solubility of anti-cancer nano drugs in aqueous solutions using genetic function approximation (GFA) algorithm. Insight Pharm Res, 1(1), 6.

60. Heidari, A. (2016). Cancer Risk Prediction and Assessment in Human Cells under Synchrotron Radiations Using Quantitative Structure Activity Relationship (QSAR) and Quantitative Structure Properties Relationship (QSPR) Studies. Int J Clin Med Imaging, 3(516), 2376-0249.

61. Heidari, A. (2016). A novel approach to biology. Electronic J Biol, 12(4), 1-2.

62. Heidari, A. (2016). Innovative biomedical equipment's for diagnosis and treatment. $J$ Bioengineer \& Biomedical Sci, 6(2), 125.

63. Heidari, A. (2016). Integrating precision cancer medicine into healthcare, medicare reimbursement changes and the practice of oncology: trends in oncology medicine and practices. J Oncol Med \& Pract, 1(2), e101.

64. Heidari, A. (2016). Promoting convergence in biomedical and biomaterials sciences and silk proteins for biomedical and biomaterials applications: an introduction to materials in medicine and bioengineering perspectives. $J$ Bioengineer \& Biomedical Sci, 6(3), e126.

65. Heidari, A. (2017). X-Ray Fluorescence and XRay Diffraction Analysis on Discrete Element Modeling of Nano Powder Metallurgy Processes in Optimal Container Design. J Powder Metall Min, 6(1), e136.

66. Heidari, A. (2017). Biomolecular Spectroscopy and Dynamics of Nano-Sized Molecules and Clusters as Cross-Linking-Induced Anti-Cancer and Immune-Oncology Nano Drugs Delivery in DNA/RNA of Human Cancer Cells' Membranes 
under Synchrotron Radiations: A Payload-Based Perspective. Arch Chem Res, 1(2), 11.

67. Heidari, A. (2017). Deficiencies in Repair of Double-Standard DNA/RNA-Binding Molecules Identified in Many Types of Solid and Liquid Tumors Oncology in Human Body for Advancing Cancer Immunotherapy Using Computer Simulations and Data Analysis. J Appl Bioinforma Comput Biol, 6(1), e104.

68. Heidari, A. (2017). Electronic coupling among the five nanomolecules shuts down quantum tunneling in the presence and absence of an applied magnetic field for indication of the dimer or other provide different influences on the magnetic behavior of single molecular magnets (SMMs) as qubits for quantum computing. Glob J Res Rev, 4(2), 69.

69. Heidari, A. (2017). Polymorphism in Nano-Sized Graphene Ligand-Induced Transformation of Au38-xAgx/xCux (SPh-tBu) 24 to Au36$\mathrm{xAgx} / \mathrm{xCux} \quad(\mathrm{SPh}-\mathrm{tBu}) \quad 24 \quad(\mathrm{x}=\quad 1-12)$ Nanomolecules for Synthesis of Au144xAgx/xCux [(SR) 60,(SC4) 60,(SC6) 60,(SC12) 60,(PET) 60,(p-MBA) 60,(F) 60,(Cl) 60,(Br) 60,(I) 60,(At) 60,(Uus) 60 and (SC6H13) 60] Nano. Journal of Nanomaterials \& Molecular Nanotechnology, 2017.

70. Heidari, A. (2017). Biomedical resource oncology and data mining to enable resource discovery in medical, medicinal, clinical, pharmaceutical, chemical and translational research and their applications in cancer research. Int J Biomed Data Min, 6(2), e103.

71. Heidari, A. (2017). Study of Synthesis, Pharmacokinetics, Pharmacodynamics, Dosing, Stability, Safety and Efficacy of Olympiadane Nanomolecules as Agent for Cancer Enzymotherapy, Immunotherapy, Chemotherapy, Radiotherapy, Hormone Therapy and Targeted Therapy under Synchrotorn Radiation. $J$ Dev Drugs, 6(2), e154.

72. Heidari, A. (2017). A novel approach to future horizon of top seven biomedical research topics to watch in 2017: alzheimer's, ebola, hypersomnia, human immunodeficiency virus (HIV), tuberculosis (TB), microbiome/antibiotic resistance and endovascular stroke. $J$ Bioengineer \& Biomedical Sci, 7(1), e127.

73. Heidari, A. (2017). Opinion on computational fluid dynamics (CFD) technique. Fluid Mech Open Acc, 4(157), 2476-2296.

74. Heidari, A. (2017). Concurrent diagnosis of oncology influence outcomes in emergency general surgery for colorectal cancer and multiple sclerosis (MS) treatment using magnetic resonance imaging (MRI) and Au329 (SR) 84, Au329-xAgx (SR) 84, Au144 (SR) 60, Au68 (SR) 36, Au30 (SR) 18, Au102 (SPh) 44, Au38 (SPh) 24, Au38 (SC2H4Ph) 24, Au21S (SAdm) 15, Au36 (pMBA) 24 and Au25 (pMBA) 18 nano clusters. J Surgery Emerg Med, 1(2), 1.
75. Heidari, A. (2017). Developmental cell biology in adult stem cells death and autophagy to trigger a preventive allergic reaction to common airborne allergens under synchrotron radiation using nanotechnology for therapeutic goals in particular allergy shots (Immunotherapy). Cell Biol (Henderson, NV), 6(1), e117.

76. Heidari, A. (2017). Changing metal powder characteristics for elimination of the heavy metals toxicity and diseases in disruption of Extracellular Matrix (ECM) proteins adjustment in cancer metastases induced by osteosarcoma, chondrosarcoma, carcinoid, carcinoma, ewing's sarcoma, fibrosarcoma and secondary hematopoietic solid or soft tissue tumors. J Powder Metall Min, 6(2), 170.

77. Heidari, A. (2017). Nanomedicine-based combination anti-cancer therapy between nucleic acids and anti-cancer nano drugs in covalent nano drugs delivery systems for selective imaging and treatment of human brain tumors using hyaluronic acid, alguronic acid and sodium hyaluronate as anti-cancer nano drugs and nucleic acids delivery under synchrotron radiation. Am J Drug Deliv, 5(2).

78. Heidari, A. (2017). Clinical trials of dendritic cell therapies for cancer exposing vulnerabilities in human cancer cells' metabolism and metabolomics: new discoveries, unique features inform new therapeutic opportunities, biotech's bumpy road to the market and elucidating the biochemical programs that support cancer initiation and progression. J Biol Med Science, 1(1), e103.

79. Heidari, A. (2017). The design graphene-based nanosheets as a new nanomaterial in anti-cancer therapy and delivery of chemotherapeutics and biological nano drugs for liposomal anti-cancer nano drugs and gene delivery. $\mathrm{Br}$ Biomed Bull, 5(2), 305.

80. Heidari, A. (2017). Integrative approach to biological networks for emerging roles of proteomics, genomics and transcriptomics in the discovery and validation of human colorectal cancer biomarkers from DNA/RNA sequencing data under synchrotron radiation. Transcriptomics, 5(2), e117.

81. Heidari, A. (2017). Elimination of the Heavy Metals Toxicity and Diseases in Disruption of Extracellular Matrix (ECM) Proteins and Cell Adhesion Intelligent Nanomolecules Adjustment in Cancer Metastases Using Metalloenzymes and under Synchrotron Radiation. Lett Health Biol Sci, 2(2), 1-4.

82. Heidari, A. (2017). Treatment of Breast Cancer Brain Metastases through a Targeted Nanomolecule Drug Delivery System Based on Dopamine Functionalized Multi-Wall Carbon Nanotubes (MWCNTs) Coated with Nano Graphene Oxide (GO) and Protonated Polyaniline (PANI) in Situ During the Polymerization of 
Aniline Autogenic Nanoparticles for the Delivery of Anti-Cancer Nano Drugs under Synchrotron Radiation. Br J Res, 4(3), 16.

83. Heidari, A. (2017). Sedative, analgesic and ultrasound-mediated gastrointestinal nano drugs delivery for gastrointestinal endoscopic procedure, nano drug-induced gastrointestinal disorders and nano drug treatment of gastric acidity. Res Rep Gastroenterol, 1(1), 1.

84. Heidari, A. (2017). Synthesis, pharmacokinetics, pharmacodynamics, dosing, stability, safety and efficacy of orphan nano drugs to treat high cholesterol and related conditions and to prevent cardiovascular disease under synchrotron radiation. J Pharm Sci Emerg Drugs, 5(1), e104.

85. Heidari, A. (2017). Non-linear compact proton synchrotrons to improve human cancer cells and tissues treatments and diagnostics through particle therapy accelerators with monochromatic microbeams. J Cell Biol Mol Sci, 2(1), 1-5.

86. Heidari, A. (2017). Design of Targeted Metal Chelation Therapeutics Nanocapsules as Colloidal Carriers and Blood-Brain Barrier (BBB) Translocation to Targeted Deliver Anti-Cancer Nano Drugs into the Human Brain to Treat Alzheimer's Disease under Synchrotron Radiation. J Nanotechnol Material Sci, 4(2), 1-5.

87. Gobato, R., \& Heidari, A. (2017). Calculations Using Quantum Chemistry for Inorganic Molecule Simulation BeLi2SeSi.American Journal of Quantum Chemistry and Molecular Spectroscopy, 2(3), 37-46.

88. Heidari, A. (2017). Different High-Resolution Simulations of Medical, Medicinal, Clinical, Pharmaceutical and Therapeutics Oncology of Human Lung Cancer Translational Anti-Cancer Nano Drugs Delivery Treatment Process under Synchrotron and X-Ray Radiations. J Med Oncol, $1(1), 1$.

89. Heidari, A. (2017). A Modern Ethnomedicinal Technique for Transformation. Prevention and Treatment of Human Malignant Gliomas Tumors into Human Benign Gliomas Tumors under Synchrotron Radiation. Am J Ethnomed, 4(1), 10.

90. Heidari, A. (2017). Active Targeted Nanoparticles for Anti-Cancer Nano Drugs Delivery across the Blood-Brain Barrier for Human Brain Cancer Treatment. J Med Chem Toxicol, 2(3), 1-5.

91. Heidari, A. (2017). Investigation of Medical, Medicinal, Clinical and Pharmaceutical Applications of Estradiol, Mestranol (Norlutin), Norethindrone (NET), Norethisterone Acetate (NETA), Norethisterone Enanthate (NETE) and Testosterone Nanoparticles as Biological Imaging, Cell Labeling, Anti-Microbial Agents and AntiCancer Nano Drugs in Nanomedicines Based Drug Delivery Systems for Anti-Cancer Targeting and Treatment. Parana Journal of Science and Education (PJSE), 3(4), 10-19.
92. Heidari, A. (2017). A comparative computational and experimental study on different vibrational biospectroscopy methods, techniques and applications for human cancer cells in tumor tissues simulation, modeling, research, diagnosis and treatment. Open J Anal Bioanal Chem, 1(1), 014-020.

93. Heidari, A. (2017). Combination of DNA/RNA ligands and linear/non-linear visible-synchrotron radiation-driven $\mathrm{n}$-doped ordered mesoporous cadmium oxide $(\mathrm{CdO})$ nanoparticles photocatalysts channels resulted in an interesting synergistic effect enhancing catalytic anti-cancer activity. Enz Eng, 6(1), 160.

94. Heidari, A. (2017). Modern approaches in designing ferritin, ferritin light chain, transferrin, beta-2 transferrin and bacterioferritin-based anticancer nano drugs encapsulating nanosphere as DNA-binding proteins from starved cells (DPS). Mod Appro Drug Des, 1(1), 000504.

95. Heidari, A. (2017). Potency of Human Interferon $\beta-1 \mathrm{a}$ and Human Interferon $\beta-1 \mathrm{~b}$ in Enzymotherapy, Immunotherapy, Chemotherapy, Radiotherapy, Hormone Therapy and Targeted Therapy of Encephalomyelitis Disseminate. $J$ Proteomics Enzymol, 6(1), e109.

96. Heidari, A. (2017). Transport therapeutic active targeting of human brain tumors enable anti-cancer nanodrugs delivery across the blood-brain barrier (BBB) to treat brain diseases using nanoparticles and nanocarriers under synchrotron radiation. $J$ Pharm Pharmaceutics, 4(2), 1-5.

97. Heidari, A., \& Brown, C. (2017). Combinatorial Therapeutic Approaches to DNA/RNA and Benzylpenicillin (Penicillin G), Fluoxetine Hydrochloride (Prozac and Sarafem), Propofol (Diprivan), Acetylsalicylic Acid (ASA)(Aspirin), Naproxen Sodium (Aleve and Naprosyn) and Dextromethamphetamine Nanocapsules with Surface Conjugated DNA/RNA to Targeted Nano Drugs for Enhanced Anti-Cancer Efficacy and Targeted Cancer Therapy Using Nano Drugs Delivery Systems. Ann Adv Chem, 1(2), 061-069.

98. Heidari, A. (2017). High-Resolution Simulations of Human Brain Cancer Translational Nano Drugs Delivery Treatment Process under Synchrotron Radiation. J Transl Res, 1(1), 1-3.

99. Heidari, A. (2017). Investigation of Anti-Cancer Nano Drugs' Effects' Trend on Human Pancreas Cancer Cells and Tissues Prevention, Diagnosis and Treatment Process under Synchrotron and XRay Radiations with the Passage of Time Using Mathematica. Current Trends Anal Bioanal Chem, 1(1), 36-41.

100.Heidari, A. (2017). Pros and Cons Controversy on Molecular Imaging and Dynamics of DoubleStandard DNA/RNA of Human Preserving Stem Cells-Binding Nano Molecules with Androgens/Anabolic Steroids (AAS) or Testosterone Derivatives through Tracking of 
Helium-4 Nucleus (Alpha Particle) Using Synchrotron Radiation. Arch Biotechnol Biomed, 1(1), 067-0100.

101.Heidari, A. (2017). Visualizing metabolic changes in probing human cancer cells and tissues metabolism using vivo $1 \mathrm{H}$ or proton NMR, 13C NMR, 15N NMR and 31P NMR spectroscopy and self-organizing maps under synchrotron radiation. SOJ Mater Sci Eng, 5(2), 1-6.

102.Heidari, A. (2017). Cavity ring-down spectroscopy (CRDS), circular dichroism spectroscopy, cold vapour atomic fluorescence spectroscopy and correlation spectroscopy comparative study on malignant and benign human cancer cells and tissues with the passage of time under synchrotron radiation. Enliven: Challenges Cancer Detect Ther, 4(2), e001.

103.Heidari, A. (2017). Laser spectroscopy, laserinduced breakdown spectroscopy and laserinduced plasma spectroscopy comparative study on malignant and benign human cancer cells and tissues with the passage of time under synchrotron radiation. Int J Hepatol Gastroenterol,3(4), 079084.

104.Heidari, A. (2017). Time-resolved spectroscopy and time-stretch spectroscopy comparative study on malignant and benign human cancer cells and tissues with the passage of time under synchrotron radiation. Enliven: Pharmacovigilance and Drug Safety, 4(2), e001.

105.Heidari, A. (2017). Overview of the role of vitamins in reducing negative effect of decapeptyl (Triptorelin Acetate or Pamoate Salts) on prostate cancer cells and tissues in prostate cancer treatment process through transformation of malignant prostate tumors into benign prostate tumors under synchrotron radiation. Open $J$ Anal Bioanal Chem, 1(1), 021-026.

106.Heidari, A. (2017). Electron phenomenological spectroscopy. Electron Paramagnetic Resonance (EPR) Spectroscopy and Electron Spin Resonance (ESR) Spectroscopy comparative study on malignant and benign human cancer cells and tissues with the passage of time under synchrotron radiation. Austin J Anal Pharm Chem, 4(3), 1091.

107.Heidari, A. (2017). Therapeutic nanomedicine different high-resolution experimental images and computational simulations for human brain cancer cells and tissues using nanocarriers deliver DNA/RNA to brain tumors under synchrotron radiation with the passage of time using mathematica and MATLAB. Madridge J Nano Tech. Sci, 2(2), 77-83.

108.Heidari, A. (2017). A Consensus and Prospective Study on Restoring Cadmium Oxide (CdO) Nanoparticles Sensitivity in Recurrent Ovarian Cancer by Extending the Cadmium Oxide (CdO) Nanoparticles-Free Interval Using Synchrotron Radiation Therapy as Antibody-Drug Conjugate for the Treatment of Limited-Stage Small Cell
Diverse Epithelial Cancers. Cancer Clin Res Rep, 1(2), e001.

109.Heidari, A. (2017). A novel and modern experimental imaging and spectroscopy comparative study on malignant and benign human cancer cells and tissues with the passage of time under white synchrotron radiation. Cancer Sci Res Open Access, 4(2), 1-8.

110.Alireza, H. (2017). Different high-resolution simulations of medical, medicinal, clinical, pharmaceutical and therapeutics oncology of human breast cancer translational nano drugs delivery treatment Process under Synchrotron and X-Ray Radiations. Journal of Oral Cancer and Research, 1(1), 12-17.

111.Heidari, A. (2017). Vibrational Decihertz (dHz), Centihertz (cHz), Millihertz $(\mathrm{mHz})$, Microhertz $(\mu \mathrm{Hz})$, Nanohertz (nHz), Picohertz (pHz), Femtohertz (fHz), Attohertz (aHz), Zeptohertz $(\mathrm{zHz})$ and Yoctohertz $(\mathrm{yHz})$ imaging and spectroscopy comparative study on malignant and benign human cancer cells and tissues under synchrotron radiation. International Journal of Biomedicine, 7(4), 335-340.

112.Heidari, A. (2017). Force Spectroscopy and Fluorescence Spectroscopy Comparative Study on Malignant and Benign Human Cancer Cells and Tissues with the Passage of Time under Synchrotron Radiation. EC Cancer, 2(5), 239-246.

113.Heidari, A. (2017). Photoacoustic Spectroscopy, Photoemission Spectroscopy and Photothermal Spectroscopy Comparative Study on Malignant and Benign Human Cancer Cells and Tissues with the Passage of Time under Synchrotron Radiation. BAOJ Cancer Res Ther, 3(3), 045-052.

114.Heidari, A. (2017). J-Spectroscopy, Exchange Spectroscopy (EXSY), Nucle 7 ar Overhauser Effect Spectroscopy (NOESY) and Total Correlation Spectroscopy (TOCSY) Comparative Study on Malignant and Benign Human Cancer Cells and Tissues under Synchrotron Radiation. EMS Eng Sci J, 1(2), 006-013.

115.Heidari, A. (2017). Neutron spin echo spectroscopy and spin noise spectroscopy comparative study on malignant and benign human cancer cells and tissues with the passage of time under synchrotron radiation. Int J Biopharm Sci, 1(1), 103-107.

116.Heidari, A. (2017). Vibrational decahertz (daHz), hectohertz $(\mathrm{hHz})$, kilohertz $(\mathrm{kHz})$, megahertz $(\mathrm{MHz})$, gigahertz $(\mathrm{GHz})$, terahertz $(\mathrm{THz})$, petahertz $(\mathrm{PHz})$, exahertz $(\mathrm{EHz})$, zettahertz $(\mathrm{ZHz})$ and yottahertz (YHz) imaging and spectroscopy comparative study on malignant and benign human cancer cells and tissues under synchrotron radiation. Madridge J Anal Sci Instrum, 2(1), 4146.

117.Heidari, A. (2018). Two-Dimensional Infrared Correlation Spectroscopy, Linear TwoDimensional Infrared Spectroscopy and NonLinear Two-Dimensional Infrared Spectroscopy 
Comparative Study on Malignant and Benign Human Cancer Cells and Tissues under Synchrotron Radiation with the Passage of Time. $J$ Mater Sci Nanotechnol, 6(1), 101.

118.Heidari, A. (2018). Fourier Transform Infrared (FTIR) Spectroscopy, Near-Infrared Spectroscopy (NIRS) and Mid-Infrared Spectroscopy (MIRS) Comparative Study on Malignant and Benign Human Cancer Cells and Tissues under Synchrotron Radiation with the Passage of Time. Int J Nanotechnol Nanomed, 3(1), 1-6.

119.Heidari, A. (2018). Infrared photo dissociation spectroscopy and infrared correlation table spectroscopy comparative study on malignant and benign human cancer cells and tissues under synchrotron radiation with the passage of time. Austin Pharmacol Pharm, 3(1), 1011.

120.Heidari, A. (2017). Novel and Transcendental Prevention, Diagnosis and Treatment Strategies for Investigation of Interaction among Human Blood Cancer Cells, Tissues, Tumors and Metastases with Synchrotron Radiation under Anti-Cancer Nano Drugs Delivery Efficacy Using MATLAB Modeling and Simulation. Madridge J Nov Drug Res, 1(1), 18-24.

121.Heidari, A. (2018). Saturated spectroscopy and unsaturated spectroscopy comparative study on malignant and benign human cancer cells and tissues with the passage of time under synchrotron radiation. Imaging J Clin Medical Sci,5(1), 001007.

122.Gobato, M. R. R., Gobato, R., \& Heidari, A. (2018). Planting of jaboticaba trees for landscape repair of degraded area. Landscape Architecture and Regional Planning, 3(1), 1-9.

123.Heidari, A. (2018). Fluorescence spectroscopy, phosphorescence spectroscopy and luminescence spectroscopy comparative study on malignant and benign human cancer cells and tissues under synchrotron radiation with the passage of time. SM J Clin. Med. Imaging, 4(1), 1018.

124.Heidari, A. (2018). Nuclear inelastic scattering spectroscopy (NISS) and nuclear inelastic absorption spectroscopy (NIAS) comparative study on malignant and benign human cancer cells and tissues under synchrotron radiation. Int $J$ Pharm Sci, 2(1), 1-14.

125.Heidari, A. (2018). X-Ray Diffraction (XRD), Powder X-Ray Diffraction (PXRD) and EnergyDispersive X-Ray Diffraction (EDXRD) Comparative Study on Malignant and Benign Human Cancer Cells and Tissues under Synchrotron Radiation. J Oncol Res, 2(1), 1-14.

126.Heidari, A. (2018). Correlation Two-Dimensional Nuclear Magnetic Resonance (NMR)(2DNMR)(COSY) Imaging and Spectroscopy Comparative Study on Malignant and Benign Human Cancer Cells and Tissues under Synchrotron Radiation. EMS Can Sci, 1(1), 001.
127.Heidari, A. (2018). Thermal spectroscopy, photothermal spectroscopy, thermal microspectroscopy, photothermal microspectroscopy, thermal macrospectroscopy and photothermal macrospectroscopy comparative study on malignant and benign human cancer cells and tissues with the passage of time under synchrotron radiation. SM J Biometrics Biostat, 3(1), 1024.

128.Heidari, A. (2018). A modern and comprehensive experimental biospectroscopic comparative study on human common cancers' cells, tissues and tumors before and after synchrotron radiation therapy. Open Acc J Oncol Med, 1(1), 1-10.

129.Heidari, A. (2018). Heteronuclear Correlation Experiments such as Heteronuclear SingleQuantum Correlation Spectroscopy (HSQC), Heteronuclear Multiple-Quantum Correlation Spectroscopy (HMQC) and Heteronuclear Multiple-Bond Correlation Spectroscopy (HMBC) Comparative Study on Malignant and Benign Human Endocrinology and Thyroid Cancer Cells and Tissues under Synchrotron Radiation. $J$ Endocrinol Thyroid Res, 3(1), 555603.

130.Scheidt, W. R., Durbin, S. M., \& Sage, J. T. (2005). Nuclear resonance vibrational spectroscopy-NRVS. Journal of inorganic biochemistry, 99(1), 60-71.

131.Heidari, A. (2018). A novel and modern experimental approach to vibrational circular dichroism spectroscopy and video spectroscopy comparative study on malignant and benign human cancer cells and tissues with the passage of time under white and monochromatic synchrotron radiation. Glob J Endocrinol Metab, 1(3), 000514000519.

132.Heidari, A. (2018). Pros and Cons Controversy on Heteronuclear Correlation Experiments such as Heteronuclear Single-Quantum Correlation Spectroscopy (HSQC), Heteronuclear MultipleQuantum Correlation Spectroscopy (HMQC) and Heteronuclear Multiple-Bond Correlation Spectroscopy (HMBC) Comparative Study on Malignant and Benign Human Cancer Cells and Tissues under Synchrotron Radiation. EMS Pharma J, 1(1), 002.

133.Heidari, A. (2018). A Modern Comparative and Comprehensive Experimental Biospectroscopic Study on Different Types of Infrared Spectroscopy of Malignant and Benign Human Cancer Cells and Tissues with the Passage of Time under Synchrotron Radiation. J Analyt Molecul Tech, 3(1), 8.

134.Heidari, A. (2018). Investigation of Cancer Types Using Synchrotron Technology for Proton Beam Therapy: An Experimental Biospectroscopic Comparative Study. European Modern Studies Journal, 2(1), 13-29.

135.Heidari, A. (2018). Saturated spectroscopy and unsaturated spectroscopy comparative study on 
malignant and benign human cancer cells and tissues with the passage of time under synchrotron radiation. Imaging J Clin Medical Sci,5(1), 001007.

136.Heidari, A. (2018). Small-Angle Neutron Scattering (SANS) and Wide-Angle X-Ray Diffraction (WAXD) Comparative Study on Malignant and Benign Human Cancer Cells and Tissues under Synchrotron Radiation. Int J Bioorg Chem Mol Biol, 6(2e), 1-6.

137.Heidari, A. (2018). Investigation of Bladder Cancer, Breast Cancer, Colorectal Cancer, Endometrial Cancer, Kidney Cancer, Leukemia, Liver, Lung Cancer, Melanoma, Non-Hodgkin Lymphoma, Pancreatic Cancer, Prostate Cancer, Thyroid Cancer and Non-Melanoma Skin Cancer Using Synchrotron Technology for Proton Beam Therapy: An Experimental Biospectroscopic Comparative Study. Ther Res Skin Dis, 1(1).

138.Heidari, A. (2018). Attenuated Total Reflectance Fourier Transform Infrared (ATR-FTIR) Spectroscopy, Micro-Attenuated Total Reflectance Fourier Transform Infrared (Micro-ATR-FTIR) Spectroscopy and Macro-Attenuated Total Reflectance Fourier Transform Infrared (MacroATR-FTIR) Spectroscopy Comparative Study on Malignant and Benign Human Cancer Cells and Tissues under Synchrotron Radiation with the Passage of Time. International Journal of Chemistry Papers, 2(1), 1-12.

139.Heidari, A. (2018). Mössbauer Spectroscopy, Mössbauer Emission Spectroscopy and 57Fe Mössbauer Spectroscopy Comparative Study on Malignant and Benign Human Cancer Cells and Tissues under Synchrotron Radiation. Acta Scientific Cancer Biology, 2(3), 17-20.

140.Heidari, A. (2018). Comparative study on malignant and benign human cancer cells and tissues under synchrotron radiation with the passage of time. Organic \& Medicinal Chem IJ, 6(1), 555676.

141.Heidari, A. (2018). Correlation Spectroscopy, Exclusive Correlation Spectroscopy and Total Correlation Spectroscopy Comparative Study on Malignant and Benign Human AIDS-Related Cancers Cells and Tissues with the Passage of Time under Synchrotron Radiation. Int J Bioanal Biomed, 2(1), 001-007.

142. Heidari, A. (2018). Biomedical instrumentation and applications of biospectroscopic methods and techniques in malignant and benign human cancer cells and tissues studies under synchrotron radiation and anti-cancer nano drugs delivery. Am J Nanotechnol Nanomed, 1(1), 001-009.

143.Heidari, A. (2018). Vivo 1H or Proton NMR, 13C NMR, 15N NMR and 31P NMR Spectroscopy Comparative Study on Malignant and Benign Human Cancer Cells and Tissues under Synchrotron Radiation. Ann Biomet Biostat, 1(1), 1001 .
144.Heidari, A. (2018). Grazing-Incidence SmallAngle Neutron Scattering (GISANS) and GrazingIncidence X-Ray Diffraction (GIXD) comparative study on malignant and benign human cancer cells, tissues and tumors under synchrotron radiation. Ann Cardiovasc Surg, 1(2), 1006.

145.Heidari, A. (2018). Adsorption Isotherms and Kinetics of Multi-Walled Carbon Nanotubes (MWCNTs), Boron Nitride Nanotubes (BNNTs), Amorphous Boron Nitride Nanotubes (a-BNNTs) and Hexagonal Boron Nitride Nanotubes ( $h-$ BNNTs) for Eliminating Carcinoma, Sarcoma, Lymphoma, Leukemia, Germ Cell Tumor and Blastoma Cancer Cells and Tissues. Clin Med Rev Case Rep, 5(1), 201.

146.Heidari, A. (2018). Correlation Spectroscopy (COSY), Exclusive Correlation Spectroscopy (ECOSY), Total Correlation Spectroscopy (TOCSY), Incredible Natural-Abundance DoubleQuantum Transfer Experiment (INADEQUATE), Heteronuclear Single-Quantum Correlation Spectroscopy (HSQC), Heteronuclear MultipleBond Correlation Spectroscopy (HMBC), Nuclear Overhauser Effect Spectroscopy (NOESY) and Rotating Frame Nuclear Overhauser Effect Spectroscopy (ROESY) Comparative Study on Malignant and Benign Human Cancer Cells and Tissues ....Acta Scientific Pharmaceutical Sciences, 2(5), 30-35.

147.Heidari, A. (2018). Small-Angle X-Ray Scattering (SAXS), Ultra-Small Angle X-Ray Scattering (USAXS), Fluctuation X-Ray Scattering (FXS).

148.Heidari, A. (2018). Pump-Probe Spectroscopy and Transient Grating Spectroscopy Comparative Study on Malignant and Benign Human Cancer Cells and Tissues with the Passage of Time under Synchrotron Radiation. Adv Material Sci Engg, 2(1), 1-7.

149.Heidari, A. (2018). Grazing-Incidence Small-Angle X-Ray Scattering (GISAXS) and GrazingIncidence Wide-An-gle X-Ray Scattering (GIWAXS) Comparative Study on Ma-lignant and Benign Human Cancer Cells and Tissues under Synchrotron Radiation. Insights Pharmacol Pharm Sci, 1(1), 1-8.

150.Heidari, A. (2018). Acoustic spectroscopy, acoustic resonance spectroscopy and auger spectroscopy comparative study on anti-cancer nano drugs delivery in malignant and benign human cancer cells and tissues with the passage of time under synchrotron radiation. Nanosci Technol, 5(1), 1-9.

151.Heidari, A. (2018). Niobium, Technetium, Ruthenium, Rhodium, Hafnium, Rhenium, Osmium and Iridium Ions Incorporation into the Nano Polymeric Matrix (NPM) by Immersion of the Nano Polymeric Modified Electrode (NPME) as Molecular Enzymes and Drug Targets for Human Cancer Cells, Tissues and Tumors Treatment under Synchrotron and 
Synchrocyclotron Radiations. Nanomed

Nanotechnol, 3(2), 000138.

152.Heidari, A. (2018). Homonuclear Correlation Experiments such as Homonuclear SingleQuantum Correlation Spectroscopy (HSQC), Homonuclear Multiple-Quantum Correlation Spectroscopy (HMQC) and Homonuclear Multiple-Bond Correlation Spectroscopy (HMBC) Comparative Study on Malignant and Benign Human Cancer Cells and Tissues under Synchrotron Radiation. Austin J Proteomics Bioinform \& Genomics, 5(1), 1024.

153.Heidari, A. (2018). Atomic Force Microscopy Based Infrared (AFM-IR) Spectroscopy and Nuclear Resonance Vibrational Spectroscopy Comparative Study on Malignant and Benign Human Cancer Cells and Tissues under Synchrotron Radiation with the Passage of Time. $J$ Appl Biotechnol Bioeng, 5(3), 142-148.

154.Heidari, A. (2018). Time-Dependent Vibrational Spectral Analysis of Malignant and Benign Human Cancer Cells and Tissues under Synchrotron Radiation. J Cancer Oncol, 2(2), 000124.

155.Heidari, A. (2018). Palauamine and Olympiadane Nano Molecules Incorporation into the Nano Polymeric Matrix (NPM) by Immersion of the Nano Polymeric Modified Electrode (NPME) as Molecular Enzymes and Drug Targets for Human Cancer Cells, Tissues and Tumors Treatment under Synchrotron and Synchrocyclotron Radiations. Arc Org Inorg Chem Sci, 3(1).

156.Gobato, R., \& Heidari, A. (2018). Infrared Spectrum and Sites of Action of Sanguinarine by Molecular Mechanics and ab initio Methods. mechanics, 30, 34 .

157.Heidari, A. (2018). Angelic Acid, Diabolic Acids, Draculin and Miraculin Nano Molecules Incorporation into the Nano Polymeric Matrix (NPM) by Immersion of the Nano Polymeric Modified Electrode (NPME) as Molecular Enzymes and Drug Targets for Human Cancer Cells, Tissues and Tumors Treatment Under Synchrotron and Synchrocyclotron Radiations. Med \& Analy Chem Int J, 2(1), 000111.

158. Heidari A. Gamma Linolenic Methyl Ester, 5Heptadeca-5, 8, 11-Trienyl 1, 3, 4-Oxadiazole-2Thiol. Sulphoquinovosyl Diacyl Glycerol, Ruscogenin, Nocturnoside B, Protodioscine B, Parquisoside-B, Leiocarposide, Narangenin. 2018:007-14.

159.Heidari, A. (2018). Heteronuclear Single-Quantum Correlation Spectroscopy (HSQC) and Heteronuclear Multiple-Bond Correlation Spectroscopy (HMBC) Comparative Study on Malignant and Benign Human Cancer Cells, Tissues and Tumors under Synchrotron and Synchrocyclotron Radiations. Chronicle of Medicine and Surgery, 2(3), 151-163.

160.Heidari, A. (2018). Heteronuclear Single-Quantum Correlation Spectroscopy (HSQC) and
Heteronuclear Multiple-Bond Correlation Spectroscopy (HMBC) Comparative Study on Malignant and Benign Human Cancer Cells, Tissues and Tumors under Synchrotron and Synchrocyclotron Radiations. Chronicle of Medicine and Surgery, 2(3), 151-163.

161.Heidari, A. (2018). Tetrakis [3, 5-bis (Trifluoromethyl) Phenyl] Borate (BARF)Enhanced Precatalyst Preparation Stabilization and Initiation (EPPSI) Nano Molecules. Medical Research and Clinical Case Reports, 2(1), 112125.

162.Heidari A. Sydnone, Münchnone, Montréalone, Mogone, Montelukast, Quebecol and Palau'amineEnhanced Precatalyst Preparation Stabilization and Initiation (EPPSI) Nano Molecules. Sur Cas Stud Op Acc J. 2018;1(3).

163.Heidari A. Fornacite, Orotic Acid, Rhamnetin, Sodium Ethyl Xanthate (SEX) and Spermine (Spermidine or Polyamine) Nanomolecules Incorporation into the Nanopolymeric Matrix (NPM). International Journal of Biochemistry and Biomolecules. 2018 Jun 26;4(1):19-36.

164.Heidari, A., \& Gobato, R. (2018). Putrescine, Cadaverine, Spermine and Spermidine-Enhanced Precatalyst Preparation Stabilization and Initiation (EPPSI) Nano Molecules. Parana Journal of Science and Education (PJSE)-v, 4(5), 1-14.

165.Heidari A. Cadaverine (1, 5-Pentanediamine or Pentamethylenediamine), Diethyl Azodicarboxylate (DEAD or DEADCAT) and Putrescine (Tetramethylenediamine) Nano Molecules Incorporation into the Nano Polymeric Matrix (NPM) by Immersion of the Nano Polymeric Modified Electrode (NPME) as Molecular Enzymes and Drug Targets for Human Cancer Cells, Tissues and Tumors Treatment under Synchrotron and Synchrocyclotron Radiations. Hiv and Sexual Health Open Access Open Journal. 2018;1(1):4-11.

166.Heidari, A. (2018). Improving the Performance of Nano-Endofullerenes in Polyaniline Nanostructure-Based Biosensors by Covering Californium Colloidal Nanoparticles with MultiWalled Carbon Nanotubes. Journal of Advances in Nanomaterials, 3(1), 1-28.

167.Gobato, R., \& Heidari, A. (2018). Molecular Mechanics and Quantum Chemical Study on Sites of Action of Sanguinarine Using Vibrational Spectroscopy Based on Molecular Mechanics and Quantum Chemical Calculations. Malaysian Journal of Chemistry, 20(1), 1-23.

168.Heidari, A. (2018). Vibrational Biospectroscopic Studies on Anti-cancer Nanopharmaceuticals (Part I). Malaysian Journal of Chemistry, 20(1), 33-73.

169.Heidari, A. (2018). Vibrational Biospectroscopic Studies on Anti-cancer Nanopharmaceuticals (Part II). Malaysian Journal of Chemistry, 20(1), 74-117.

170.Heidari, A. (2018). Uranocene (U (C8H8) 2) and Bis (Cyclooctatetraene) Iron (Fe $(\mathrm{C} 8 \mathrm{H} 8) 2$ or $\mathrm{Fe}$ 
(COT) 2)-Enhanced Precatalyst Preparation Stabilization and Initiation (EPPSI) Nano Molecules. Chemistry Reports, 1(2), 1-16.

171.Heidari, A. (2018). Biomedical Systematic and Emerging Technological Study on Human Malignant and Benign Cancer Cells and Tissues Biospectroscopic Analysis under Synchrotron Radiation. Glob Imaging Insights, 3(3), 1-7.

172.Heidari, A. (2018). Deep-Level Transient Spectroscopy and X-Ray Photoelectron Spectroscopy (XPS) Comparative Study on Malignant and Benign Human Cancer Cells and Tissues with the Passage of Time under Synchrotron Radiation. Res Dev Material Sci, 7(2), 000659.

173.Heidari, A. (2018). C70-Carboxyfullerenes Nano Molecules Incorporation into the Nano Polymeric Matrix (NPM) by Immersion of the Nano Polymeric Modified Electrode (NPME) as Molecular Enzymes and Drug Targets for Human Cancer Cells, Tissues and Tumors Treatment under Synchrotron and Synchrocyclotron Radiations. Glob Imaging Insights, 3(3), 1-7.

174.Heidari, A. (2018). The effect of temperature on cadmium oxide $(\mathrm{CdO})$ nanoparticles produced by synchrotron radiation in the human cancer cells, tissues and tumors. International Journal of Advanced Chemistry, 6(2), 140-156.

175.Heidari, A. (2018). A Clinical and Molecular Pathology Investigation of Correlation Spectroscopy (COSY), Exclusive Correlation Spectroscopy (ECOSY), Total Correlation Spectroscopy (TOCSY), Heteronuclear SingleQuantum Correlation Spectroscopy (HSQC) and Heteronuclear Multiple-Bond Correlation Spectroscopy (HMBC) Comparative Study on Malignant and Benign Human Cancer Cells, Tissues and Tumors under Synchrotron and Synchrocyclotron Radiations Using Cyclotron versus Synchrotron, Synchrocyclotron and the Large Hadron Collider .... European Journal of Advances in Engineering and Technology, 5(7), 414-426.

176.Heidari, A. (2018). Nano molecules incorporation into the nano polymeric matrix (NPM) by immersion of the nano polymeric modified electrode (NPME) as molecular enzymes and drug targets for human cancer cells, tissues and tumors treatment under synchrotron and synchrocyclotron radiations. J Oncol Res, 1(1), 1-20.

177.Heidari, A. (2018). Use of Molecular Enzymes in the Treatment of Chronic Disorders. Canc Oncol Open Access J, 1(1), 12-15.

178. Heidari, A. (2018). Vibrational biospectroscopic study and chemical structure analysis of unsaturated polyamides nanoparticles as anticancer polymeric nanomedicines using synchrotron radiation. International Journal of Advanced Chemistry, 6(2), 167-189.
179.Heidari, A. (2018). Adamantane, Irene, Naftazone and Pyridine-Enhanced Precatalyst Preparation Stabilization and Initiation (PEPPSI) Nano Molecules. Madridge J Nov Drug Res, 2(1), 61-67.

180.Heidari, A. (2018). Heteronuclear Single-Quantum Correlation Spectroscopy (HSQC) and Heteronuclear Multiple-Bond Correlation Spectroscopy (HMBC) Comparative Study on Malignant and Benign Human Cancer Cells, Tissues and Tumors under Synchrotron and Synchrocyclotron Radiations. Chronicle of Medicine and Surgery, 2(3), 151-163.

181.Heidari, A., \& Gobato, R. (2018). A Novel Approach to Reduce Toxicities and to Improve Bioavailabilities of DNA/RNA of Human Cancer Cells-Containing Cocaine (Coke), Lysergide (Lysergic Acid Diethyl Amide or LSD), $\Delta^{9}$ Tetrahydrocannabinol (THC) $\left[(-)-\right.$ trans $-\Delta^{9}-$ Tetrahydrocannabinol], Theobromine (Xantheose), Caffeine, Aspartame (APM)(NutraSweet) and Zidovudine (ZDV)[Azidothymidine (AZT)] as Anti-Cancer Nano Drugs by Coassembly of Dual Anti-Cancer Nano Drugs to Inhibit DNA/RNA of Human Cancer Cells Drug Resistance. Parana Journal of Science and Education, 4(6), 1-17.

182.Heidari, A., \& Gobato, R. (2018). Ultraviolet Photoelectron Spectroscopy (UPS) and UltravioletVisible (UV-Vis) Spectroscopy Comparative Study on Malignant and Benign Human Cancer Cells and Tissues with the Passage of Time under Synchrotron Radiation. Parana Journal of Science and Education, 4(6), 18-33.

183.Gobato, R., Heidari, A., \& Mitra, A. (2018). The Creation of $\mathrm{C} 13 \mathrm{H} 20 \mathrm{BeLi} 2 \mathrm{SeSi}$. The Proposal of a Bio-Inorganic Molecule, Using Ab Initio Methods for the Genesis of a Nano Membrane. Arc Org Inorg Chem Sci, 3(4).

184.Gobato, R., Heidari, A., \& Mitra, A. (2018). Using the Quantum Chemistry for Genesis of a Nano Biomembrane with a Combination of the Elements Be, Li, Se, Si, C and H. J Nanomed Res, 7(4), 241252.

185.Gobato, R., Heidari, A., \& Mitra, A. (2018). Using the Quantum Chemistry for Genesis of a Nano Biomembrane with a Combination of the Elements Be, Li, Se, Si, C and H. J Nanomed Res, 7(4), 241252.

186.Heidari, A. (2018). Bastadins and BastaranesEnhanced Precatalyst Preparation Stabilization and Initiation (EPPSI) Nano Molecules. Glob Imaging Insights, 3(4), 1-7.

187.Heidari, A. (2018). Fucitol, Pterodactyladiene, DEAD or DEADCAT (DiEthyl AzoDiCArboxylaTe), Skatole, the NanoPutians, Thebacon, Pikachurin, Tie Fighter, Spermidine and Mirasorvone Nano Molecules Incorporation into the Nano Polymeric Matrix (NPM) by Immersion of the Nano Polymeric Modified Electrode (NPME) as Molecular Enzymes and Drug Targets for Human Cancer Cells, Tissues and Tumors 
Treatment under Synchrotron and Synchrocyclotron Radiations. Glob Imaging Insights, 3(4), 1-8.

188.Dadvar, E., \& Heidari, A. (2018). A Review on Separation Techniques of Graphene Oxide (GO)/Base on Hybrid Polymer Membranes for Eradication of Dyes and Oil Compounds: Recent Progress in Graphene Oxide (GO)/Base on Polymer Membranes-Related Nanotechnologies. Clin Med Rev Case Rep, 5, 228.

189.Heidari, A., \& Gobato, R. (2018). First-Time Simulation of Deoxyuridine Monophosphate (dUMP)(Deoxyuridylic Acid or Deoxyuridylate) and Vomitoxin (Deoxynivalenol (DON)) $((3 \alpha, 7 \alpha)-$ 3, 7, 15-Trihydroxy-12, 13-Epoxytrichothec-9En-8-One)-Enhanced Precatalyst Preparation Stabilization and Initiation (EPPSI) Nano Molecules Incorporation into the Nano Polymeric Matrix (NPM) by Immersion of the Nano Polymeric Modified Electrode (NPME) as Molecular Enzymes and Drug Targets for Human Cancer Cells, Tissues and Tumors Treatment under Synchrotron and .... Parana Journal of Science and Education, 4(6), 46-67.

190.Heidari, A. (2018). Buckminsterfullerene (Fullerene), Bullvalene, Dickite and Josiphos Ligands Nano Molecules Incorporation into the Nano Polymeric Matrix (NPM) by Immersion of the Nano Polymeric Modified Electrode (NPME) as Molecular Enzymes and Drug Targets for Human Hematology and Thromboembolic Diseases Prevention, Diagnosis and Treatment under Synchrotron and Synchrocyclotron Radiations. Glob Imaging Insights, 3(4), 1-7.

191.Heidari, A. (2018). Fluctuation X-Ray Scattering (FXS) and Wide-Angle X-Ray Scattering (WAXS) Comparative Study on Malignant and Benign Human Cancer Cells and Tissues under Synchrotron Radiation. Glob Imaging Insights, 3(4), 1-7.

192.Heidari, A. (2018). A Novel Approach to Correlation Spectroscopy (COSY), Exclusive Correlation Spectroscopy (ECOSY), Total Correlation Spectroscopy (TOCSY), Incredible Natural-Abundance Double-Quantum Transfer Experiment (INADEQUATE), Heteronuclear Single-Quantum Correlation Spectroscopy (HSQC), Heteronuclear Multiple-Bond Correlation Spectroscopy (HMBC), Nuclear Overhauser Effect Spectroscopy (NOESY) and Rotating Frame Nuclear Overhauser Effect Spectroscopy (ROESY) Comparative Study on Malignant and Benign Human Cancer .... Glob Imaging Insights, 3(5), 19.

193.Heidari, A. (2018). Terphenyl-Based Reversible Receptor with Rhodamine, Rhodamine-Based Molecular Probe, Rhodamine-Based Using the Spirolactam Ring Opening, Rhodamine B with Ferrocene Substituent, Calix [4] Arene-Based Receptor, Thioether+ Aniline-Derived Ligand
Framework Linked to a Fluorescein Platform, Mercuryfluor-1 (Flourescent Probe), N, N'Dibenzyl-1， 4, 10, 13-Tetraraoxa-7, 16Diazacyclooctadecane and Terphenyl-Based Reversible Receptor with Pyrene and Quinoline as the Fluorophores-Enhanced Precatalyst Preparation .... Glob Imaging Insights, 3(5), 1-9.

194.Heidari, A. (2018). Small-Angle X-Ray Scattering (SAXS), Ultra-Small Angle X-Ray Scattering (USAXS), Fluctuation X-Ray Scattering (FXS).

195.Heidari, A. (2018). Nuclear Resonant Inelastic XRay Scattering Spectroscopy (NRIXSS) and Nuclear Resonance Vibrational Spectroscopy (NRVS) Comparative Study on Malignant and Benign Human Cancer Cells and Tissues under Synchrotron Radiation. Glob Imaging Insights, 3(5), 1-7.

196.Heidari, A. (2018). Small-Angle X-Ray Scattering (SAXS) and Ultra-Small Angle X-Ray Scattering (USAXS) Comparative Study on Malignant and Benign Human Cancer Cells and Tissues under Synchrotron Radiation. Glob Imaging Insights, 3(5), 1-7.

197.Heidari, A. (2018). Curious Chloride $(\mathrm{CmCl} 3)$ and Titanic Chloride (TiCl4)-Enhanced Precatalyst Preparation Stabilization and Initiation (EPPSI) Nano Molecules for Cancer Treatment and Cellular Therapeutics. J. Cancer Research and Therapeutic Interventions, 1(1), 01-10.

198.Gobato, R., Gobato, M. R. R., Heidari, A., \& Mitra, A. (2018). Spectroscopy and dipole moment of the molecule $\mathrm{C} 13 \mathrm{H} 20 \mathrm{BeLi} 2 \mathrm{SeSi}$ via quantum chemistry using $\mathrm{Ab}$ initio, Hartree-Fock method in the base set CC-pVTZ and $6-311 \mathrm{G}^{* *}(3 \mathrm{df}$, 3pd). American Journal of Quantum Chemistry and Molecular Spectroscopy, 2(1), 9-17.

199.Heidari, A. (2018). C60 and C70-Encapsulating Carbon Nanotubes Incorporation into the Nano Polymeric Matrix (NPM) by Immersion of the Nano Polymeric Modified Electrode (NPME) as Molecular Enzymes and Drug Targets for Human Cancer Cells, Tissues and Tumors Treatment under Synchrotron and Synchrocyclotron Radiations. Integr Mol Med, 5(3), 1-8.

200.Heidari, A. (2018). Two-Dimensional (2D) $1 \mathrm{H}$ or Proton NMR, $13 \mathrm{C}$ NMR, $15 \mathrm{~N}$ NMR and $31 \mathrm{P}$ NMR Spectroscopy Comparative Study on Malignant and Benign Human Cancer Cells and Tissues under Synchrotron Radiation with the Passage of Time. Glob Imaging Insights, 3(6), 1-8.

201.Heidari, A. (2018). FT-Raman Spectroscopy, Coherent Anti-Stokes Raman Spectroscopy (CARS) and Raman Optical Activity Spectroscopy (ROAS) Comparative Study on Malignant and Benign Human Cancer Cells and Tissues with the Passage of Time under Synchrotron Radiation. Glob Imaging Insights, 3(6), 1-8.

202.Heidari, A. (2018). A Modern and Comprehensive Investigation of Inelastic Electron Tunneling Spectroscopy (IETS) and Scanning Tunneling 
Spectroscopy on Malignant and Benign Human Cancer Cells, Tissues and Tumors through Optimizing Synchrotron Microbeam Radiotherapy for Human Cancer Treatments and Diagnostics: An Experimental Biospectroscopic Comparative Study. Glob Imaging Insights, 3(6), 1-8.

203.Heidari, A. (2018). A Hypertension Approach to Thermal Infrared Spectroscopy and Photothermal Infrared Spectroscopy Comparative Study on Malignant and Benign Human Cancer Cells and Tissues under Synchrotron Radiation with the Passage of Time. Glob Imaging Insights, 3(6), 1-8.

204.Heidari, A. (2018). Incredible Natural-Abundance Double-Quantum Transfer Experiment (INADEQUATE), Nuclear Overhauser Effect Spectroscopy (NOESY) and Rotating Frame Nuclear Overhauser Effect Spectroscopy (ROESY) Comparative Study on Malignant and Benign Human Cancer Cells and Tissues under Synchrotron Radiation. Glob Imaging Insights, 3(6), 1-8.

205.Heidari, A. (2018). 2-Amino-9-((1S, 3R, 4R)-4Hydroxy-3-(Hydroxymethyl)-2-

Methylenecyclopentyl)-1H-Purin-6 (9H)-One, 2Amino-9-((1R, 3R, 4R)-4-Hydroxy-3(Hydroxymethyl)-2-Methylenecyclopentyl)-1HPurin-6 (9H)-One, 2-Amino-9-((1R, 3R, 4S)-4Hydroxy-3-(Hydroxymethyl)-2-

Methylenecyclopentyl)-1H-Purin-6 (9H)-One and 2-Amino-9-((1S, 3R, 4S)-4-Hydroxy-3(Hydroxymethyl)-2-Methylenecyclopentyl)-1HPurin-6 (9H)-One-Enhanced Precatalyst Preparation Stabilization and Initiation Nano Molecules", Glob Imaging Insights. Hartree-Fock Method in the Base Set CC-Trends in Res, 2, 1-8.

206.Gobato, R., Gobato, M. R. R., Heidari, A., \& Mitra, A. (2018). Spectroscopy and dipole moment of the molecule $\mathrm{C} 13 \mathrm{H} 20 \mathrm{BeLi} 2 \mathrm{SeSi}$ via quantum chemistry using $\mathrm{Ab}$ initio, Hartree-Fock method in the base set CC-pVTZ and 6-311G**(3df, $3 \mathrm{pd})$. American Journal of Quantum Chemistry and Molecular Spectroscopy, 2(1), 9-17.

207.Heidari, A. (2018). Production of Electrochemiluminescence (ECL) Biosensor Using Os-Pd/HfC Nanocomposites for Detecting and Tracking of Human Gastroenterological Cancer Cells, Tissues and Tumors. Int J Med Nano Res, 5(1), 022-034.

208.Heidari, A. (2018). Enhancing the Raman Scattering for Diagnosis and Treatment of Human Cancer Cells, Tissues and Tumors Using Cadmium Oxide (CdO) Nanoparticles. J Toxicol Risk Assess, 4(1), 012-025.

209.Heidari, A. (2018). Human Malignant and Benign Human Cancer Cells and Tissues Biospectroscopic Analysis under Synchrotron Radiation Using AntiCancer Nano Drugs Delivery. Integr Mol Med, 5(5), 1-13.

210.Heidari, A. (2018). Analogous Nano Compounds of the Form $\mathrm{M}(\mathrm{C} 8 \mathrm{H} 8) 2$ Exist for $\mathrm{M}=(\mathrm{Nd}, \mathrm{Tb}, \mathrm{Pu}$,
Pa, Np, Th, and Yb)-Enhanced Precatalyst Preparation Stabilization and Initiation (EPPSI) Nano Molecules. Integr Mol Med, 5(5), 1-8.

211.Heidari, A. (2018). Hadron Spectroscopy, Baryon Spectroscopy and Meson Spectroscopy Comparative Study on Malignant and Benign Human Cancer Cells and Tissues under Synchrotron Radiation. Integr Mol Med, 5(5), 1-8.

212.Gobato, R., Gobato, M. R. R., \& Heidari, A. (2019). Raman spectroscopy study of the nano molecule c 13 h 20 beli 2 sesi using ab initio and hartree-fock methods in the basis set cc-pvtz and 6$311 \mathrm{~g} * *(3 \mathrm{df}, 3 \mathrm{pd})$. International Journal of Advanced Engineering and Science, 8(1), 14-35.

213.Heidari, A., \& Gobato, R. (2019). Evaluating the effect of anti-cancer nano drugs dosage and reduced leukemia and polycythemia vera levels on trend of the human blood and bone marrow cancers under synchrotron radiation. Trends in Res, 2(1), 18.

214.Heidari, A., \& Gobato, R. (2019). Assessing the variety of synchrotron, synchrocyclotron and laser radiations and their roles and applications in human cancer cells, tissues and tumors diagnosis and treatment. Trends in Res, 2(1), 1-8.

215.Heidari, A., \& Gobato, R. (2019). Pros and cons controversy on malignant human cancer cells, tissues and tumors transformation process to benign human cancer cells, tissues and tumors. Trends in Res, 2(1), 1-8.

216.Heidari, A., \& Gobato, R. (2019). ThreeDimensional (3D) Simulations of Human Cancer Cells, Tissues and Tumors for Using in Human Cancer Cells, Tissues and Tumors Diagnosis and Treatment as a Powerful Tool in Human Cancer Cells, Tissues and Tumors Research and AntiCancer Nano Drugs Sensitivity and Delivery Area Discovery and Evaluation. Trends in Res, 2(1), 1-8.

217.Heidari, A., \& Gobato, R. (2019). Investigation of energy production by synchrotron, synchrocyclotron and laser radiations in human cancer cells, tissues and tumors and evaluation of their effective on human cancer cells, tissues and tumors treatment trend. Trends in Res, 2(1), 1-8.

218.Heidari, A., \& Gobato, R. (2019). High-resolution mapping of DNA/RNA hypermethylation and hypomethylation process in human cancer cells, tissues and tumors under synchrotron radiation. Trends in Res, 2(2), 1-9.

219.Heidari, A. (2019). A Novel and Comprehensive Study on Manufacturing and Fabrication Nanoparticles Methods and Techniques for Processing Cadmium Oxide (CdO) Nanoparticles Colloidal Solution. Glob Imaging Insights, 4(1), 18.

220.Heidari, A. (2019). A Combined Experimental and Computational Study on the Catalytic Effect of Aluminum Nitride Nanocrystal (AIN) on the Polymerization of Benzene, Naphthalene, 
Anthracene, Phenanthrene, Chrysene and Tetracene. Glob Imaging Insights, 4(1), 1-8.

221.Heidari, A. (2019). Novel Experimental and Three-Dimensional (3D) Multiphysics Computational Framework of Michaelis-Menten Kinetics for Catalyst Processes Innovation, Characterization and Carrier Applications. Glob Imaging Insights, 4(1), 1-8.

222.Heidari, A. (2019). The Hydrolysis Constants of Copper (I) $(\mathrm{Cu}+)$ and Copper (II) $(\mathrm{Cu} 2+)$ in Aqueous Solution as a Function of $\mathrm{pH}$ Using a Combination of $\mathrm{pH}$ Measurement and Biospectroscopic Methods and Techniques. Glob Imaging Insights, 4(1), 1-8.

223.Heidari, A. (2019). Vibrational biospectroscopic study of ginormous virus-sized macromolecule and polypeptide macromolecule as mega macromolecules using attenuated total reflectancefourier transform infrared (ATR-FTIR) spectroscopy and mathematica 11.3. Glob Imaging Insights, 4(1), 1-8.

224.Heidari, A. (2019). Three-Dimensional (3D) Imaging Spectroscopy of Carcinoma, Sarcoma, Leukemia, Lymphoma, Multiple Myeloma, Melanoma, Brain and Spinal Cord Tumors, Germ Cell Tumors, Neuroendocrine Tumors and Carcinoid Tumors under Synchrotron Radiation. Glob Imaging Insights, 4(1), 1-9.

225.Gobato, R., Gobato, M. R. R., \& Heidari, A. (2019). Storm Vortex in the Center of Paraná State on June 6, 2017: A Case Study. Sumerianz Journal of Scientific Research, 2(2), 24-31.

226.Gobato, R., Gobato, M. R. R., \& Heidari, A. (2019). Attenuated Total Reflection-Fourier Transform Infrared (ATR-FTIR) Spectroscopy Study of the Nano Molecule C13H20BeLi2SeSi Using ab initio and Hartree-Fock Methods in the Basis Set RHF/CC-pVTZ and RHF/6311G**(3df, 3pd): An Experimental Challenge to Chemists. Chemistry Reports, 2(1), 1-26.

227.Heidari, A. (2019). Three-Dimensional (3D) Imaging Spectroscopy of Carcinoma, Sarcoma, Leukemia, Lymphoma, Multiple Myeloma, Melanoma, Brain and Spinal Cord Tumors, Germ Cell Tumors, Neuroendocrine Tumors and Carcinoid Tumors under Synchrotron Radiation. Glob Imaging Insights, 4(1), 1-9.

228. Gobato, R., Gobato, M. R. R., Heidari, A., \& Mitra, A. (2019). New Nano-Molecule KurumiC13H 20BeLi2SeSi/C13H19BeLi2SeSi, and Raman Spectroscopy Using ab initio, Hartree-Fock Method in the Base Set CC-pVTZ and 6311G**(3df, 3pd). J Anal Pharm Res, 8(1), 1-6.

229.Heidari, A., Esposito, J., \& Caissutti, A. (2019). The Importance of Attenuated Total Reflectance Fourier Transform Infrared (ATR-FTIR) and Raman Biospectroscopy of Single-Walled Carbon Nanotubes (SWCNT) and Multi-Walled Carbon Nanotubes (MWCNT) in Interpreting Infrared and
Raman Spectra of Human Cancer Cells, Tissues and Tumors. Oncogen, 2(2), 1-21.

230.Heidari, A. (2019). Mechanism of Action and Their Side Effects at a Glance Prevention, Treatment and Management of Immune System and Human Cancer Nano Chemotherapy. Nanosci Technol, 6(1), 1-4.

231.Heidari, A., Esposito, J., \& Caissutti, A. (2019). The Quantum Entanglement Dynamics Induced by Non-Linear Interaction between a Moving Nano Molecule and a Two-Mode Field with TwoPhoton Transitions Using Reduced Von Neumann Entropy and Jaynes-Cummings Model for Human Cancer Cells, Tissues and Tumors Diagnosis. Int J Crit Care Emerg Med, 5(2), 071-084.

232.Heidari, A., Esposito, J., \& Caissutti, A. (2019). Maitotoxin Time-Resolved Absorption and Resonance FT-IR and Raman Biospectroscopy and Density Functional Theory (DFT) Investigation of Vibronic-Mode Couplin g Structure in Vibrational Spectra Analysis: A Spectro-scopic Study on an Anti-Cancer Drug. J Biomed Engg Res, 1(1).

233.Heidari, A., Esposito, J., \& Caissutti, A. (2019). Enterotoxin Time-Resolved Absorption and Resonance FT-IR and Raman Biospectroscopy and Density Functional Theory (DFT) Inves-tigation of Vibronic-Mode Coupling Structure in Vibrational Spectra Analysis. JRL J Sci Technol. 2019; volliss 2: jst 1001, 1 .

234.Gobato, R., Gobato, M. R. R., Heidari, A., \& Mitra, A. (2018). Spectroscopy and dipole moment of the molecule $\mathrm{C} 13 \mathrm{H} 20 \mathrm{BeLi} 2 \mathrm{SeSi}$ via quantum chemistry using $\mathrm{Ab}$ initio, Hartree-Fock method in the base set CC-pVTZ and 6-311G**(3df, 3pd). American Journal of Quantum Chemistry and Molecular Spectroscopy, 2(1), 9-17.

235.Heidari, A., Esposito, J., \& Caissutti, A. (2019). Maitotoxin Time-Resolved Absorption and Resonance FT-IR and Raman Biospectroscopy and Density Functional Theory (DFT) Investigation of Vibronic-Mode Couplin g Structure in Vibrational Spectra Analysis: A Spectro-scopic Study on an Anti-Cancer Drug. J Biomed Engg Res, 1(1).

236.Heidari, A. (2019). Potential and Theranostics Applications of Novel Anti-Cancer Nano Drugs Delivery Systems in Preparing for Clinical Trials of Synchrotron Microbeam Radiation Therapy (SMRT) and Synchrotron Stereotactic Radiotherapy (SSRT) for Treatment of Human Cancer Cells, Tissues and Tumors Using Image Guided Synchrotron Radiotherapy (IGSR). Ann Nanosci Nanotechnol, 3(1), 1006-1019.

237.Heidari, A., Esposito, J., \& Caissutti, A. (2019). Study of Anti-Cancer Properties of Thin Layers of Cadmium Oxide (CdO) Nanostructure. Int J Analyt Bioanalyt Methods, 1(1), 003-022.

238.Heidari, A., Esposito, J., \& Caissutti, A. (2019). Maitotoxin Time-Resolved Absorption and Resonance FT-IR and Raman Biospectroscopy and Density Functional Theory (DFT) Investigation of 
Vibronic-Mode Couplin g Structure in Vibrational Spectra Analysis: A Spectro-scopic Study on an Anti-Cancer Drug. J Biomed Engg Res, 1(1).

239. Heidari, A. (2019). Clinical and Medical Pros and Cons of Human Cancer Cells' Enzymotherapy, Immunotherapy, Chemotherapy, Radiotherapy, Hormone Therapy and Targeted Therapy Process under Synchrotron Radiation: A Case Study on Mechanism of Action and Their Side Effects. Parana Journal of Science and Education, 5(3), 1-23.

240.Heidari, A. (2019). The importance of the power in CMOS inverter circuit of synchrotron and synchrocyclotron radiations using $50(\mathrm{~nm})$ and 100 $(\mathrm{nm})$ technologies and reducing the voltage of power supply. Radiother Oncol Int, 1(1), 10021015.

241.Heidari, A., Esposito, J., \& Caissutti, A. (2019). The Importance of Quantum Hydrodynamics (QHD) Approach to Single-Walled Carbon Nanotubes (SWCNT) and Multi-Walled Carbon Nanotubes (MWCNT) in Genetic Science. SCIOL Genet Sci, 2(1), 113-129.

242.Heidari, A., Esposito, J., \& Caissutti, A. (2019). Anatoxin-a and Anatoxin-a (s) Time-Resolved Absorption and Resonance FT-IR and Raman Biospectroscopy and Density Functional Theory (DFT) Investigation of Vibronic-Mode Coupling Structure in Vibrational Spectra Analysis. Saudi J Biomed Res, 4(4), 174-194.

243.Gobato, R., Gobato, M. R. R., \& Heidari, A. (2019). Evidence of Tornado Storm Hit the Counties of Rio Branco do Ivaí and Rosario de Ivaí, Southern Brazil. Sci Lett, 7(1), 9.

244.Jeyaraj, M., Mahalingam, V., Indhuleka, A., Sennu, P., Ho, M. S., \& Heidari, A. (2019). Chemical Analysis of Surface Water Quality of River Noyyal Connected Tank in Tirupur District, Tamil Nadu, India. IWRA (India) Journal (Half Yearly Technical Journal of Indian Geographical Committee of IWRA), 8(2), 23-28.

245.Heidari, A., Esposito, J., \& Caissutti, A. (2019). 6Methoxy-8-[[6-Methoxy-8-[[6-Methoxy-2Methyl-1-(2-Methylpropyl)-3, 4-Dihydro-1HIsoquinolin-7-yl] Oxy]-2-Methyl-1-(2Methylpropyl)-3, 4-Dihydro-1H-Isoquinolin-7yl] Oxy]-2-Methyl-1-(2-Methylpropyl)-3, 4Dihydro-1H-Isoquinolin-7-ol Time-Resolved Absorption and Resonance FT-IR and Raman Biospectroscopy and Density Functional Theory (DFT) Investigation of Vibronic-Mode Coupling Structure in Vibrational Spectra Analysis". J. Adv. Phys. Chem, 1(1), 1-6.

246.Heidari, A., Esposito, J., \& Caissutti, A. (2019). Shiga Toxin and Shiga-Like Toxin (SLT) TimeResolved Absorption and Resonance FT-IR and Raman Biospectroscopy and Density Functional Theory (DFT) Investigation of Vibronic-Mode Coupling Structure in Vibrational Spectra Analysis. Annal Biostat \& Biomed Appli, 2(3), 1-4.
247.Heidari, A., Esposito, J., \& Caissutti, A. (2019). Enterotoxin Time-Resolved Absorption and Resonance FT-IR and Raman Biospectroscopy and Density Functional Theory (DFT) Inves-tigation of Vibronic-Mode Coupling Structure in Vibrational Spectra Analysis. JRL J Sci Technol. 2019; volliss 2: jst1001, 1 .

248.Heidari, A., Esposito, J., \& Caissutti, A. (2019). Okadaic Acid Time-Resolved Absorption and Resonance FT-IR and Raman Biospectroscopy and Density Functional Theory (DFT) Investigation of Vibronic-Mode Coupling Structure in Vibrational Spectra Analysis. Int $J$ Analyt Bioanalyt Methods, 1(1), 1-19.

249.Heidari, A. (2019). Investigation of the Processes of Absorption, Distribution, Metabolism and Elimination (ADME) as Vital and Important Factors for Modulating Drug Action and Toxicity. Open Access J Oncol,2(1), 180010180012.

250.Heidari, A., Esposito, J., \& Caissutti, A. (2019). Maitotoxin Time-Resolved Absorption and Resonance FT-IR and Raman Biospectroscopy and Density Functional Theory (DFT) Investigation of Vibronic-Mode Couplin g Structure in Vibrational Spectra Analysis: A Spectro-scopic Study on an Anti-Cancer Drug. J Biomed Engg Res, 1(1).

251.Gobato, R., Gobato, M. R. R., \& Heidari, A. (2019). Calculation by UFF method of frequencies and vibrational temperatures of the unit cell of the rhodochrosite crystal. International Journal of Advanced Chemistry, 7(2), 77-81.

252.Heidari, A., Esposito, J., \& Caissutti, A. (2019). Tetrodotoxin (TTX) Time-Resolved Absorption and Resonance FT-IR and Raman Biospectroscopy and Density Functional Theory (DFT) Investigation of Vibronic-Mode Coupling Structure in Vibrational Spectra Analysis. Journal of New Developments in Chemistry, 2(3), 26.

253.Heidari, A., Esposito, J., \& Caissutti, A. (2019). The Importance of Analysis of Vibronic-Mode Coupling Structure in Vibrational Spectra of Supramolecular Aggregates of $\left(\mathrm{CA}^{*} \mathrm{M}\right)$ Cyanuric Acid (CA) and Melamine (M) beyond the FranckCondon Approximation. Journal of Clinical and Medical Images, 2(2), 1-20.

254.Heidari, A., Esposito, J., \& Caissutti, A. (2019). Microcystin-LR Time-Resolved Absorption and Resonance FT-IR and Raman Biospectroscopy and Density Functional Theory (DFT) Investigation of Vibronic-Mode Coupling Structure in Vibrational Spectra Analysis. Malaysian Journal of Chemistry, 21(1), 70-95.

255.Heidari, A., Esposito, J., \& Caissutti, A. (2019). Botulinum Toxin Time-Resolved Absorption and Resonance FT-IR and Raman Biospectroscopy and Density Functional Theory (DFT) Investigation of Vibronic-Mode Coupling Structure in Vibrational Spectra Analysis. Journal of Mechanical Design and Vibration, 7(1), 1-15. 
256.Heidari, A., Esposito, J., \& Caissutti, A. (2019). Enterotoxin Time-Resolved Absorption and Resonance FT-IR and Raman Biospectroscopy and Density Functional Theory (DFT) Inves-tigation of Vibronic-Mode Coupling Structure in Vibrational Spectra Analysis. JRL J Sci Technol. 2019; volliss 2: jst1001, 1 .

257.Heidari, A., Esposito, J., \& Caissutti, A. (2019). Surugatoxin (SGTX) Time-Resolved Absorption and Resonance FT-IR and Raman Biospectroscopy and Density Functional Theory (DFT) Investigation of Vibronic-Mode Coupling Structure in Vibrational Spectra Analysis. Cientific Clinical Oncology Journal, 1(2), 14-18.

258.Heidari, A., Esposito, J., \& Caissutti, A. (2019). Maitotoxin Time-Resolved Absorption and Resonance FT-IR and Raman Biospectroscopy and Density Functional Theory (DFT) Investigation of Vibronic-Mode Couplin g Structure in Vibrational Spectra Analysis: A Spectro-scopic Study on an Anti-Cancer Drug. J Biomed Engg Res, 1(1).

259.Heidari, A., Esposito, J., \& Caissutti, A. (2019). Gonyautoxin (GTX) Time-Resolved Absorption and Resonance FT-IR and Raman Biospectroscopy and Density Functional Theory (DFT) Investigation of Vibronic-Mode Coupling Structure in Vibrational Spectra Analysis. Cientific Clinical Oncology Journal, 1(2), 24-28.

260.Heidari, A., Esposito, J., \& Caissutti, A. (2019). Maitotoxin Time-Resolved Absorption and Resonance FT-IR and Raman Biospectroscopy and Density Functional Theory (DFT) Investigation of Vibronic-Mode Couplin g Structure in Vibrational Spectra Analysis: A Spectro-scopic Study on an Anti-Cancer Drug. J Biomed Engg Res, 1(1).

261.Heidari, A., Esposito, J., \& Caissutti, A. (2019). Dihydrokainic Acid Time-Resolved Absorption and Resonance FT-IR and Raman Biospectroscopy and Density Functional Theory (DFT) Investigation of Vibronic-Mode Coupling Structure in Vibrational Spectra Analysis. Cientific Drug Delivery Research, 1(1), 07-12.

262.Heidari, A., Esposito, J., \& Caissutti, A. (2019). Maitotoxin Time-Resolved Absorption and Resonance FT-IR and Raman Biospectroscopy and Density Functional Theory (DFT) Investigation of Vibronic-Mode Couplin g Structure in Vibrational Spectra Analysis: A Spectro-scopic Study on an Anti-Cancer Drug. J Biomed Engg Res, 1(1).

263.Heidari, A., Esposito, J., \& Caissutti, A. (2019). Maitotoxin Time-Resolved Absorption and Resonance FT-IR and Raman Biospectroscopy and Density Functional Theory (DFT) Investigation of Vibronic-Mode Couplin g Structure in Vibrational Spectra Analysis: A Spectro-scopic Study on an Anti-Cancer Drug. J Biomed Engg Res, 1(1).

264.Heidari, A., Esposito, J., \& Caissutti, A. (2019). Enterotoxin Time-Resolved Absorption and Resonance FT-IR and Raman Biospectroscopy and Density Functional Theory (DFT) Inves-tigation of
Vibronic-Mode Coupling Structure in Vibrational Spectra Analysis. JRL J Sci Technol. 2019; volliss 2: jst1001, 1.

265.Heidari, A., Esposito, J., \& Caissutti, A. (2019). Kainic Acid (Kainite) Time-Resolved Absorption and Resonance FT-IR and Raman Biospectroscopy and Density Functional Theory (DFT) Investigation of Vibronic-Mode Coupling Structure in Vibrational Spectra Analysis. Cientific Journal of Neurology, 1(2), 02-07.

266.Heidari, A., Esposito, J., \& Caissutti, A. (2019). Maitotoxin Time-Resolved Absorption and Resonance FT-IR and Raman Biospectroscopy and Density Functional Theory (DFT) Investigation of Vibronic-Mode Couplin g Structure in Vibrational Spectra Analysis: A Spectro-scopic Study on an Anti-Cancer Drug. J Biomed Engg Res, 1(1).

267.Heidari, A., Esposito, J., \& Caissutti, A. (2019). Spider Toxin and Raventoxin Time-Resolved Absorption and Resonance FT-IR and Raman Biospectroscopy and Density Functional Theory (DFT) Investigation of Vibronic-Mode Coupling Structure in Vibrational Spectra Analysis. Parana Journal of Science and Education, 5(4), 1-28.

268.Heidari, A., Esposito, J., \& Caissutti, A. (2019). Enterotoxin Time-Resolved Absorption and Resonance FT-IR and Raman Biospectroscopy and Density Functional Theory (DFT) Inves-tigation of Vibronic-Mode Coupling Structure in Vibrational Spectra Analysis. JRL J Sci Technol. 2019; volliss 2: jst1001, 1.

269.Heidari, A., Esposito, J., \& Caissutti, A. (2019). Brevetoxin A and B Time-Resolved Absorption and Resonance FT-IR and Raman Biospectroscopy and Density Functional Theory (DFT) Investigation of Vibronic-Mode Coupling Structure in Vibrational Spectra Analysis. Cientific Drug Delivery Research, 1(2), 11-16.

270.Heidari, A., Esposito, J., \& Caissutti, A. (2019). Enterotoxin Time-Resolved Absorption and Resonance FT-IR and Raman Biospectroscopy and Density Functional Theory (DFT) Inves-tigation of Vibronic-Mode Coupling Structure in Vibrational Spectra Analysis. JRL J Sci Technol. 2019; volliss 2: jst1001, 1 .

271.Heidari, A., Esposito, J., \& Caissutti, A. (2019). Enterotoxin Time-Resolved Absorption and Resonance FT-IR and Raman Biospectroscopy and Density Functional Theory (DFT) Inves-tigation of Vibronic-Mode Coupling Structure in Vibrational Spectra Analysis. JRL J Sci Technol. 2019; volliss 2: jst 1001, 1 .

272.Heidari, A., Esposito, J., \& Caissutti, A. (2019). Maitotoxin Time-Resolved Absorption and Resonance FT-IR and Raman Biospectroscopy and Density Functional Theory (DFT) Investigation of Vibronic-Mode Couplin g Structure in Vibrational Spectra Analysis: A Spectro-scopic Study on an Anti-Cancer Drug. J Biomed Engg Res, 1(1). 
273.Heidari, A., Esposito, J., \& Caissutti, A. (2019). Neurotoxin and Alpha-Neurotoxin Time-Resolved Absorption and Resonance FT-IR and Raman Biospectroscopy and Density Functional Theory (DFT) Investigation of Vibronic-Mode Coupling Structure in Vibrational Spectra Analysis. $J$ Biomed Sci \& Res, 3(6), 550-563.

274.Heidari, A., Esposito, J., \& Caissutti, A. (2019). Antillatoxin (ATX) Time-Resolved Absorption and Resonance FT-IR and Raman Biospectroscopy and Density Functional Theory (DFT) Investigation of Vibronic-Mode Coupling Structure. American Journal of Optics and Photonics, 7(1), 18-27.

275.Gobato, R., Gobato, M. R. R., \& Heidari, A. (2019). Calculation by UFF method of frequencies and vibrational temperatures of the unit cell of the rhodochrosite crystal. International Journal of Advanced Chemistry, 7(2), 77-81.

276.Heidari, A., Esposito, J., \& Caissutti, A. (2019). Analysis of Vibronic-Mode Coupling Structure in Vibrational Spectra of Fuzeon as a 36 Amino Acid Peptide for HIV Therapy beyond the MultiDimensional Franck-Condon Integrals Approximation. International Journal of Advanced Chemistry, 7(2), 82-96.

277.Heidari, A., Esposito, J., \& Caissutti, A. (2019). Debromoaplysiatoxin Time-Resolved Absorption and Resonance FT-IR and Raman Biospectroscopy and Density Functional Theory (DFT) Investigation of Vibronic-Mode Coupling Structure in Vibrational Spectra Analysis. Applied Chemistry, 2(1), 17-54.

278.Heidari, A., Esposito, J., \& Caissutti, A. (2019). Enterotoxin Time-Resolved Absorption and Resonance FT-IR and Raman Biospectroscopy and Density Functional Theory (DFT) Inves-tigation of Vibronic-Mode Coupling Structure in Vibrational Spectra Analysis. JRL J Sci Technol. 2019; volliss 2: jst1001, 1 .

279.Gobato, R., Gobato, M. R. R., Heidari, A., \& Mitra, A. (2019). Rhodochrosite Optical Indicatrix. viXra. org> Condensed Matter> viXra: 1908. 0455. URL: $\quad$ http://vixra. org/abs/1908.0455. Available in: Aug, 22.

280.Heidari, A., Esposito, J., \& Caissutti, A. (2019). Enterotoxin Time-Resolved Absorption and Resonance FT-IR and Raman Biospectroscopy and Density Functional Theory (DFT) Inves-tigation of Vibronic-Mode Coupling Structure in Vibrat

281.Heidari, A., Esposito, J., \& Caissutti, A. (2019). Maitotoxin Time-Resolved Absorption and Resonance FT-IR and Raman Biospectroscopy and Density Functional Theory (DFT) Investigation of Vibronic-Mode Couplin g Structure in Vibrational Spectra Analysis: A Spectro-scopic Study on an Anti-Cancer Drug. J Biomed Engg Res, 1(1).

282.Heidari, A., Esposito, J., \& Caissutti, A. (2019). Maitotoxin Time-Resolved Absorption and Resonance FT-IR and Raman Biospectroscopy and
Density Functional Theory (DFT) Investigation of Vibronic-Mode Couplin g Structure in Vibrational Spectra Analysis: A Spectro-scopic Study on an Anti-Cancer Drug. J Biomed Engg Res, 1(1).

283.Heidari, A., Esposito, J., \& Caissutti, A. (2019). 6Methoxy-8-[[6-Methoxy-8-[[6-Methoxy-2-

Methyl-1-(2-Methylpropyl)-3, 4-Dihydro-1HIsoquinolin-7-yl] Oxy]-2-Methyl-1-(2Methylpropyl)-3, 4-Dihydro-1H-Isoquinolin-7yl] Oxy]-2-Methyl-1-(2-Methylpropyl)-3, 4Dihydro-1H-Isoquinolin-7-ol Time-Resolved Absorption and Resonance FT-IR and Raman Biospectroscopy and Density Functional Theory (DFT) Investigation of Vibronic-Mode Coupling Structure in Vibrational Spectra Analysis". J. Adv. Phys. Chem, 1(1), 1-6.

284.Heidari, A. (2019). Comparison of Synchrotron Radiation and Synchrocyclotron Radiation Performance in Monitoring of Human Cancer Cells, Tissues and Tumors. Clin Case Studie Rep, 2(3), 1-12.

285.Heidari, A., Esposito, J., \& Caissutti, A. (2019). Maitotoxin Time-Resolved Absorption and Resonance FT-IR and Raman Biospectroscopy and Density Functional Theory (DFT) Investigation of Vibronic-Mode Couplin g Structure in Vibrational Spectra Analysis: A Spectro-scopic Study on an Anti-Cancer Drug. J Biomed Engg Res, 1(1).

286.Heidari, A., Esposito, J., \& Caissutti, A. (2019). Maitotoxin Time-Resolved Absorption and Resonance FT-IR and Raman Biospectroscopy and Density Functional Theory (DFT) Investigation of Vibronic-Mode Couplin g Structure in Vibrational Spectra Analysis: A Spectro-scopic Study on an Anti-Cancer Drug. J Biomed Engg Res, 1(1).

287.Heidari, A., Esposito, J., \& Caissutti, A. (2019). Symbiodinolide Time-Resolved Absorption and Resonance FT-IR and Raman Biospectroscopy and Density Functional Theory (DFT) Investigation of Vibronic-Mode Coupling Structure in Vibrational Spectra Analysis. Clin Case Studie Rep, 2(3), 1-14.

288.Heidari, A., Esposito, J., \& Caissutti, A. (2019). Saxitoxin Time-Resolved Absorption and Resonance FT-IR and Raman Biospectroscopy and Density Functional Theory Investigation of Vibronic-Mode Coupling Structure in Vibrational Spectra Analysis. Am J Exp Clin Res, 6(4), 364377.

289.Person, W. B., Zilles, B., \& Rogers, J. D. (1982). Hartree-fock Methods Analysis Protonated Rhodochrosite Crystal and Potential in the Elimination of Cancer Cells Through Synchrotron Radiation. RGAJ Mol Struct, 80, 297.

290.Gobato, R., Dosh, I. K. K., Heidari, A., Mitra, A., \& Gobato, M. R. R. (2019). Perspectives on the Elimination of Cancer Cells Using Rhodochrosite Crystal Through Synchrotron Radiation, and Absorption the Tumoral and Non-Tumoral Tissues. Arch Biomed Eng \& Biotechnol, 3(2), 1-2. 
291.Gobato, R., Gobato, M. R. R., Heidari, A., \& Mitra, A. (2019). Unrestricted hartree-fock computational simulation in a protonated rhodochrosite crystal. Phys Astron Int J,3(6), 220228.

292.Heidari, A., Schmitt, K., Henderson, M., \& Besana, E. (2019). Perspectives On Sub-nanometer Level of Electronic Structure of the Synchrotron With Mendelevium Nanoparticles For Elimination of Human Cancer Cells, Tissues and Tumors Treatment Using Mathematica 12.0. Journal of Energy Conservation, 1(2), 46.

293.Heidari, A., Schmitt, K., Henderson, M., \& Besana, E. (2020). The effectiveness of the treatment human cancer cells, tissues and tumors using darmstadtium nanoparticles and synchrotron radiation. International Journal of Advanced Engineering and Science, 9(1), 9-38.

294.Heidari, A., Schmitt, K., Henderson, M., \& Besana, E. (2020). The effectiveness of the treatment human cancer cells, tissues and tumors using darmstadtium nanoparticles and synchrotron radiation. International Journal of Advanced Engineering and Science, 9(1), 9-38.

295.Heidari, A., Schmitt, K., Henderson, M., \& Besana, E. (2020). The effectiveness of the treatment human cancer cells, tissues and tumors using darmstadtium nanoparticles and synchrotron radiation. International Journal of Advanced Engineering and Science, 9(1), 9-38.

296.Heidari, A., Schmitt, K., Henderson, M., Besana. E. (2019). "Using 3D Finite Element Method (FEM) as an Optothermal Human Cancer Cells, Tissues and Tumors Treatment in Simulation of Interaction of Synchrotron Radiation Emission as a Function of the Beam Energy and Uranium Nanoparticles", Nano Prog, 1(2), 1-6, 2019.

297.Heidari, A., Schmitt, K., Henderson, M., Besana, E. (2019). "A New Approach to Interaction between Beam Energy and Erbium Nanoparticles”, Saudi J Biomed Res, 4(11): 372-396.

298.Heidari, A., Schmitt, K., Henderson, M., Besana, E. (2019). "Consideration of Energy Functions and Wave Functions of the Synchrotron Radiation and Samarium Nanoparticles Interaction during Human Cancer Cells, Tissues and Tumors Treatment Process", Sci. Int. (Lahore), 31 (6), 885-908, 2019.

299.Heidari, A., Schmitt, K., Henderson, M., Besana, E. (2019). "An Outlook on Optothermal Human Cancer Cells, Tissues and Tumors Treatment Using Lanthanum Nanoparticles under Synchrotron Radiation", Journal of Materials Physics and Chemistry, 7(1), 29-45.

300.Heidari, A., Schmitt, K., Henderson, M., Besana, E. (2019). "Effectiveness of Einsteinium Nanoparticles in Optothermal Human Cancer Cells, Tissues and Tumors Treatment under Synchrotron Radiation", Journal of Analytical Oncology, 8(1), 43-62.
301.Heidari, A., Schmitt, K., Henderson, M., Besana, E. (2019). "Study of Relation between Synchrotron Radiation and Dubnium Nanoparticles in Human Cancer Cells, Tissues and Tumors Treatment Process", Int. Res. J. Applied Sci., 1(4), 1-20.

302.Heidari, A., Schmitt, K., Henderson, M., Besana, E. (2019). "A Novel Prospect on Interaction of Synchrotron Radiation Emission and Europium Nanoparticles for Human Cancer Cells, Tissues and Tumors Treatment”, European Modern Studies Journal, 3(5), 11-24.

303.Heidari, A., Schmitt, K., Henderson, M., Besana, E. (2019). "Advantages, Effectiveness and Efficiency of Using Neodymium Nanoparticles by $3 D$ Finite Element Method (FEM) as an Optothermal Human Cancer Cells, Tissues and Tumors Treatment under Synchrotron Radiation", International Journal of Advanced Chemistry, 7(2), 119-135.

304.Heidari, A., Schmitt, K., Henderson, M., Besana, E. (2019). "Role and Applications of Promethium Nanoparticles in Human Cancer Cells, Tissues and Tumors Treatment”, Scientific Modelling and Research, 4(1): 8-14.

305.Heidari, A., Esposito, J., Caissutti, A.(2019). "Maitotoxin Time-Resolved Absorption and Resonance FT-IR and Raman Biospectroscopy and Density Functional Theory (DFT) Investigation of Vibronic-Mode Coupling Structure in Vibrational Spectra Analysis: A Spectroscopic Study on an Anti-Cancer Drug”, Glob Imaging Insights, 4(2), $1-13$.

306.Heidari, A., Esposito, J., \& Caissutti, A. (2019). Enterotoxin Time-Resolved Absorption and Resonance FT-IR and Raman Biospectroscopy and Density Functional Theory (DFT) Inves-tigation of Vibronic-Mode Coupling Structure in Vibrational Spectra Analysis. JRL J Sci Technol. 2019; volliss 2: jst1001, 1 .

307.Heidari, A., Esposito, J., Caissutti, A.(2019). "Time-Resolved Resonance FT-IR and Raman Spectroscopy and Density Functional Theory Investigation of Vibronic-Mode Coupling Structure in Vibrational Spectra of Nanopolypeptide Macromolecule beyond the Multi-Dimensional Franck-Condon Integrals Approximation and Density Matrix Method”, Glob Imaging Insights, 4(2), 1-14.

308.Heidari, A., Esposito, J., \& Caissutti, A. (2019). Enterotoxin Time-Resolved Absorption and Resonance FT-IR and Raman Biospectroscopy and Density Functional Theory (DFT) Inves-tigation of Vibronic-Mode Coupling Structure in Vibrational Spectra Analysis. JRL J Sci Technol. 2019; volliss 2: jst 1001, 1 .

309.Heidari, A., Esposito, J., \& Caissutti, A. (2019). Enterotoxin Time-Resolved Absorption and Resonance FT-IR and Raman Biospectroscopy and Density Functional Theory (DFT) Inves-tigation of Vibronic-Mode Coupling Structure in Vibrational 
Spectra Analysis. JRL J Sci Technol. 2019; volliss 2: jst1001, 1 .

310.Heidari, A., Esposito, J., \& Caissutti, A. (2019). Maitotoxin Time-Resolved Absorption and Resonance FT-IR and Raman Biospectroscopy and Density Functional Theory (DFT) Investigation of Vibronic-Mode Couplin g Structure in Vibrational Spectra Analysis: A Spectro-scopic Study on an Anti-Cancer Drug. J Biomed Engg Res, 1(1).

311.Heidari, A., Esposito, J., \& Caissutti, A. (2019). Enterotoxin Time-Resolved Absorption and Resonance FT-IR and Raman Biospectroscopy and Density Functional Theory (DFT) Inves-tigation of Vibronic-Mode Coupling Structure in Vibrational Spectra Analysis. JRL J Sci Technol. 2019; volliss 2: jst1001, 1 .

312.Heidari, A., Esposito, J., \& Caissutti, A. (2019). Maitotoxin Time-Resolved Absorption and Resonance FT-IR and Raman Biospectroscopy and Density Functional Theory (DFT) Investigation of Vibronic-Mode Couplin g Structure in Vibrational Spectra Analysis: A Spectro-scopic Study on an Anti-Cancer Drug. J Biomed Engg Res, 1(1).

313.Heidari, A., Esposito, J., \& Caissutti, A. (2019). Enterotoxin Time-Resolved Absorption and Resonance FT-IR and Raman Biospectroscopy and Density Functional Theory (DFT) Inves-tigation of Vibronic-Mode Coupling Structure in Vibrational Spectra Analysis. JRL J Sci Technol. 2019; volliss 2: jst1001, 1 .

314.Heidari, A., Esposito, J., \& Caissutti, A. (2019). Enterotoxin Time-Resolved Absorption and Resonance FT-IR and Raman Biospectroscopy and Density Functional Theory (DFT) Inves-tigation of Vibronic-Mode Coupling Structure in Vibrational Spectra Analysis. JRL J Sci Technol. 2019; volliss 2: jst1001, 1 .

315.Heidari, A., Esposito, J., \& Caissutti, A. (2019). Enterotoxin Time-Resolved Absorption and Resonance FT-IR and Raman Biospectroscopy and Density Functional Theory (DFT) Inves-tigation of Vibronic-Mode Coupling Structure in Vibrational Spectra Analysis. JRL J Sci Technol. 2019; volliss 2: jst1001, 1 .

316.Heidari, A., Schmitt, K., Henderson, M., Besana, E. (2019). "Investigation of Moscovium Nanoparticles as Anti-Cancer Nano Drugs for Human Cancer Cells, Tissues and Tumors Treatment”, Elixir Appl. Chem. 137A, 5394353963.

317.Heidari, A., Schmitt, K., Henderson, M., Besana, E. (2019). "Study of Function of the Beam Energy and Holmium Nanoparticles Using 3D Finite Element Method (FEM) as an Optothermal Human Cancer Cells, Tissues and Tumors Treatment", European Journal of Advances in Engineering and Technology, 6(12): 34-62.

318.Heidari, A., Schmitt, K., Henderson, M., Besana, E. (2019). "Human Cancer Cells, Tissues and Tumors Treatment Using Dysprosium
Nanoparticles”, Asian J. Mat. Chem. 4 (3-4), 4751.

319.Heidari, A., Schmitt, K., Henderson, M., Besana, E. (2019). "Simulation of Interaction of Synchrotron Radiation Emission as a Function of the Beam Energy and Plutonium Nanoparticles Using 3D Finite Element Method (FEM) as an Optothermal Human Cancer Cells, Tissues and Tumors Treatment”, J. Cancer Research and Cellular Therapeutics, 2(4), 1-19.

320.Heidari, A., Schmitt, K., Henderson, M., Besana, E. (2019). "Study of Gadolinium Nanoparticles Delivery Effect on Human Cancer Cells, Tissues and Tumors Treatment under Synchrotron Radiation”, Applied Chemistry, 2(2)55-97.

321.Heidari, A., Schmitt, K., Henderson, M., Besana, E., \& Gobato, R. Pros and Cons of Livermorium Nanoparticles for Human Cancer Cells, Tissues and Tumors Treatment under Synchrotron Radiation Using Mathematica 12.0.

322.Gobato, R., Gobato, M. R. R., Heidari, A., \& Mitra, A. (2020). Challenging Giants. Hartree-Fock Methods Analysis Protonated Rhodochrosite Crystal and Potential in the Elimination of Cancer Cells through Synchrotron Radiation. Biomedical Journal of Scientific \& Technical Research, 25(1), 18843-18848.

323.Heidari, A., Schmitt, K., Henderson, M., Besana, E. (2019). "Simulation of Interaction between Ytterbium Nanoparticles and Human Gum Cancer Cells, Tissues and Tumors Treatment under Synchrotron Radiation", Dent Oral Maxillofac Res, 5(5), 1-18.

324.Heidari, A., Schmitt, K., Henderson, M., Besana, E. (2019). "Modelling of Interaction between Curium Nanoparticles and Human Gum Cancer Cells, Tissues and Tumors Treatment under Synchrotron Radiation", Dent Oral Maxillofac Res, 5(5), 1-18.

325.Heidari, A., Schmitt, K., Henderson, M., Besana, E. (2019). "Study of Berkelium Nanoparticles Delivery Effectiveness and Efficiency on Human Gum Cancer Cells, Tissues and Tumors Treatment under Synchrotron Radiation", Dent Oral Maxillofac Res, 5(5), 1-18.

326.Heidari, A., Schmitt, K., Henderson, M., Besana, E. (2019). "Fermium Nanoparticles Delivery Mechanism in Human Gum Cancer Cells, Tissues and Tumors Treatment under Synchrotron Radiation", Dent Oral Maxillofac Res, 5(5), 1-17.

327.A. Heidari, K. Schmitt, M. Henderson, E. Besana, "Advantages of Lawrencium Nanoparticles for Human Gum Cancer Cells, Tissues and Tumors Treatment under Synchrotron Radiation”, Dent Oral Maxillofac Res, Volume 5, Issue 5, Pages 118, 2019.

328.Heidari, A., Schmitt, K., Henderson, M., Besana, E. (2019). "Pros and Cons of the Roentgenium Nanoparticles for Human Gum Cancer Cells, 
Tissues and Tumors Treatment under Synchrotron Radiation”, Dent Oral Maxillofac Res, 5(5), 1-17.

329.Heidari, A., Schmitt, K., Henderson, M., Besana, E. (2019). "Imagery of Flerovium Nanoparticles Delivery Process in Human Gum Cancer Cells, Tissues and Tumors Treatment under Synchrotron Radiation”, Dent Oral Maxillofac Res, 5(5), 1-18.

330.A. Heidari, J. Esposito, A. Caissutti, "Maitotoxin Time-Resolved Absorption and Resonance FT-IR and Raman Biospectroscopy and Density Functional Theory (DFT) Investigation of Vibronic-Mode Coupling Structure in Vibrational Spectra Analysis: A Spectroscopic Study on an Anti-Gum Cancer Drug”, Dent Oral Maxillofac Res, Volume 5, Issue 5, Pages 1-16, 2019.

331.Heidari, A., Esposito, J., \& Caissutti, A. (2019). Enterotoxin Time-Resolved Absorption and Resonance FT-IR and Raman Biospectroscopy and Density Functional Theory (DFT) Inves-tigation of Vibronic-Mode Coupling Structure in Vibrational Spectra Analysis. JRL J Sci Technol. 2019; volliss 2: jst1001, 1 .

332.Heidari, A., \& Gobato, R. (2019). Assessing the variety of synchrotron, synchrocyclotron and laser radiations and their roles and applications in human cancer cells, tissues and tumors diagnosis and treatment. Trends in Res, 2(1), 1-8.

333.Heidari, A., Schmitt, K., Henderson, M., Besana, E. (2019). "Dramaturgy of Technetium Nanoparticles Delivery Process in Human Gum Cancer Cells, Tissues and Tumors Treatment under Synchrotron Radiation", Dent Oral Maxillofac Res, 5(6), 1-19.

334.Heidari, A., \& Gobato, R. (2019). Investigation of energy production by synchrotron, synchrocyclotron and laser radiations in human cancer cells, tissues and tumors and evaluation of their effective on human cancer cells, tissues and tumors treatment trend. Trends in Res, 2(1), 1-8.

335.Heidari, A., Schmitt, K., Henderson, M., Besana, E. (2019). "Appearance Check of Rhodium Nanoparticles Delivery Trend in Human Gum Cancer Cells, Tissues and Tumors Treatment under Synchrotron Radiation", Dent Oral Maxillofac Res, 5(6), 1-19.

336.Heidari, A., Schmitt, K., Henderson, M., Besana, E. (2019). "Orientation Rhenium Nanoparticles Delivery Target on Human Gum Cancer Cells, Tissues and Tumors under Synchrotron Radiation,", Dent Oral Maxillofac Res, 5(6), 1-18.

337.Heidari, A., Schmitt, K., Henderson, M., Besana, E. (2019). "Drug Delivery Systems (DDSs) of Osmium Nanoparticles on Human Gum Cancer Cells, Tissues and Tumors Treatment under Synchrotron Radiation", Dent Oral Maxillofac Res, 5(6), 1-18.

338.Heidari, A., Schmitt, K., Henderson, M., Besana, E. (2019). "Development of Successful Formulations for Oral Drug Delivery Concepts of Iridium Nanoparticles in Human Gum Cancer
Cells, Tissues and Tumors Treatment under Synchrotron Radiation", Dent Oral Maxillofac Res, 5(6), 1-19.

339.Heidari, A., Schmitt, K., Henderson, M., \& Besana, E. (2019). Perspectives on Sub-nanometer Level of Electronic Structure of the Synchrotron With Mendelevium Nanoparticles For Elimination of Human Cancer Cells, Tissues and Tumors Treatment Using Mathematica 12.0. Journal of Energy Conservation, 1(2), 46.

340.Heidari, A., Schmitt, K., Henderson, M., Besana, E. (2020). "Types of Drug Delivery System Slideshare of Protactinium Nanoparticles in Human Gum Cancer Cells, Tissues and Tumors Treatment under Synchrotron Radiation”, Dent Oral Maxillofac Res, 6(1), 1-17.

341.Heidari, A., Schmitt, K., Henderson, M., Besana, E. (2020). "New Drug Delivery System in Pharmaceutics of Neptunium Nanoparticles in Human Gum Cancer Cells, Tissues and Tumors Treatment under Synchrotron Radiation”, Dent Oral Maxillofac Res, 6(1), 1-18.

342.Heidari, A., Schmitt, K., Henderson, M., Besana, E. (2020). "Drug Delivery Describes the Method and Approach to Delivering Drugs or Pharmaceuticals and Other Xenobiotics to Their Site of Action within Radon Nanoparticles Effects on Human Gum Cancer Cells, Tissues and Tumors Treatment under Synchrotron Radiation”, Dent Oral Maxillofac Res, 6(1), 1-18.

343.Heidari, A., Schmitt, K., Henderson, M., Besana, E. (2020). "Applications of Oganesson Nanoparticles in Increasing Rapidly with the Promise of Targeted and Efficient Drug Delivery in Human Gum Cancer Cells, Tissues and Tumors Treatment under Synchrotron Radiation”, Dent Oral Maxillofac Res, 6(1), 1-19.

344.Heidari, A., Schmitt, K., Henderson, M., Besana, E. (2020). "Wheeler-Feynman Time- Symmetric Study of Effectiveness and Efficiency of Terbium Nanoparticles Delivery Mechanism in Human Cancer Cells, Tissues and Tumors under Synchrotron Radiation”, Frontiers Drug Chemistry Clinical Res, 3(1), 1-13.

345.Heidari, A., Schmitt, K., Henderson, M., Besana, E. (2019). "Simulation of Interaction of Synchrotron Radiation Emission as a Function of the Beam Energy and Californium Nanoparticles Using 3D Finite Element Method (FEM) as an Optothermal Human Cancer Cells, Tissues and Tumors Treatment”, Oncol Res: Open Acce, 1(1): $1-17$.

346.Heidari, A. (2020). "Market Analysis of Glycobiology and Glycochemistry”, J Genet Disor Genet Rep. 8: 1.

347.Heidari, A., Schmitt, K., Henderson, M., Besana, E. (2020). "Synchrotron Radiation Emission as a Function of the Beam Energy and Thorium Nanoparticles", International Medicine; 2(1): 6773. 
348.Heidari, A., Schmitt, K., Henderson, M., Besana, E. (2020). "Stochastic Study of Relativistic Lutetium Nanoparticles Moving in a Quantum Field of Synchrotron Radiation Emission When Charged Lutetium Nanoparticles Are Accelerated Radially in Human Cancer Cells, Tissues and Tumors Treatment", Frontiers Drug Chemistry Clinical Res, 3(1), 1-15.

349.Heidari, A., Caissutti, A., Henderson, M., Schmitt, K., Besana, E., Esposito, J., Peterson, V. (2020). "Recent New Results and Achievements of California South University (CSU) BioSpectroscopy Core Research Laboratory for COVID-19 or 2019-nCoV Treatment: Diagnosis and Treatment Methodologies of "Coronavirus", Journal of Current Viruses and Treatment Methodologies, 1(1), 3-41.

350.Heidari, A., Schmitt, K., Henderson, M., \& Besana, E. (2020). Study of Human Cancer Cells, Tissues and Tumors Treatment Through Interaction Between Synchrotron Radiation and Cerium Nanoparticles. Science Letters, 8(1), 7-17.

351.Heidari, A., Schmitt, K., Henderson, M., Besana, E. (2020). "Study of Characteristic Polarization and the Frequencies Generated in Interaction of Synchrotron Radiation Emission and Actinium Nanoparticles in Human Cancer Cells, Tissues and Tumors Treatment Process", Parana Journal of Science and Education (PJSE)- 6(3), (13-47) April 15.

352.Heidari, A., Schmitt, K., Henderson, M., Besana, E. (2020). "Californium Nanoparticles and Human Cancer Treatment: Commemorating the 100 th (1920-2020) Anniversary of the California South University (CSU)", Parana Journal of Science and Education (PJSE) 6(3), (48-83) April 15.

353.Heidari, A., Schmitt, K., Henderson, M., \& Besana, E. (2020). Study of Human Cancer Cells, Tissues and Tumors Treatment through Interaction between Synchrotron Radiation and Cerium Nanoparticles. Science Letters, 8(1), 7-17.

354.Lee, G. (2016). Cancerous immunoglobulins and potential applications in cancer immunodiagnostics and immunotherapy. Immunome Research, 12(S2), 46.

355.Heidari, A., Peterson, V. (2020). “An Encyclopedic Review on Stereotactic Hypofractionated Radiotherapy, Re-Irradiation, and Cancer Genome Research", International Journal of Advanced Chemistry, 8(1): 59-74.

356. Heidari, A., Peterson, V. (2020). "A Pervasive Review on Biomarker in Cervical Intraepithelial Lesions and Carcinoma", International Journal of Advanced Chemistry, 8(1): 75-88.

357.Heidari, A., Schmitt, K., Henderson, M., Besana, E. (2020). "Hereditary Immunity in Cancer", International Journal of Advanced Chemistry, 8(1): 94-110.
358.Gobato, R., Gobato, M. R. R., Heidari, A., Mitra, A., Dosh, I. K. K. (2020). "Secret Messages in Enigmatic Playful Texts”, ABEB, 4(2): 1-10.

359.Heidari, A., Gobato, R., Gobato, M. R. R., Mitra, A. (2020). "Hartree-Fock Methods Analysis Protonated Rhodochrosite Crystal and Potential in the Elimination of Cancer Cells through Synchrotron Radiation Using Small-Angle X-Ray Scattering (SAXS), Ultra-Small Angle X-Ray Scattering (USAXS), Fluctuation X-Ray Scattering (FXS), Wide-Angle X-Ray Scattering (WAXS), Grazing-Incidence Small-Angle X-Ray Scattering (GISAXS), Grazing-Incidence Wide-Angle X-Ray Scattering (GIWAXS) and Small-Angle Neutron Scattering (SANS)”, AJAN, 1(1): 1-8.

360.Heidari, A., Gobato, R., Dosh, I. K. K., Mitra, A., Gobato, M. R. R. (2020). "Single Layer Bioinorganic Membrane Using the Kurumi Molecule", AJAN, 1(1): 16-20.

361.Heidari, A., Schmitt, K., Henderson, M., Besana, E. (2020). "Study of Pulsed Time Structure of Nobelium Nanoparticles in Human Cancer Cells, Tissues and Tumors Treatment Process Which Covers from Microwaves to Hard X-Rays", Dent Oral Maxillofac Res, 6(2), 1-17.

362.Heidari, A., Schmitt, K., Henderson, M., Besana, E. (2020). "Abraham-Lorentz-Dirac Force Approach to Interaction of Synchrotron Radiation Emission as a Function of the Beam Energy and Rutherfordium Nanoparticles Using 3D Finite Element Method (FEM) as an Optothermal Human Cancer Cells, Tissues and Tumors Treatment", Dent Oral Maxillofac Res, 6(2), 1-17.

363.Heidari, A., Schmitt, K., Henderson, M., Besana, E. (2020). "Liénard-Wiechert Field Study of Interaction of Synchrotron Radiation Emission as a Function of the Beam Energy and Seaborgium Nanoparticles Using 3D Finite Element Method (FEM) as an Optothermal Human Cancer Cells, Tissues and Tumors Treatment", Dent Oral Maxillofac Res, 6(2), 1-17.

364.Heidari, A., Schmitt, K., Henderson, M., Besana, E. (2020). "Lorenz Gauge, Electric and Magnetic Fields Study of Interaction of Gravitationally Accelerating Ions through the Super Contorted 'Tubular' Polar Areas of Magnetic Fields and Hassium Nanoparticles", Dent Oral Maxillofac Res, 6(2), 1-18.

365.Heidari, A., Schmitt, K., Henderson, M., Besana, E. (2020). "Scalar Abraham-Lorentz- DiracLangevin Equation, Radiation Reaction and Vacuum Fluctuations Simulation of Interaction of Synchrotron Radiation Emission as a Function of the Beam Energy and Tennessine Nanoparticles Using 3D Finite Element Method (FEM) as an Optothermal Human Cancer Cells, Tissues and Tumors Treatment", Dent Oral Maxillofac Res, 6(2), 1-17.

366.Heidari, A., Schmitt, K., Henderson, M., \& Besana, E. (2020). The effectiveness of the treatment 
human cancer cells, tissues and tumors using darmstadtium nanoparticles and synchrotron radiation. International Journal of Advanced Engineering and Science, 9(1), 9-38.

367.Heidari, A. (2020). "Future Advanced Study of Thin Layers of DNA/RNA Hybrid Molecule Nanostructure", J Mol Nanot Nanom, 2(1): 110116.

368.Heidari, A. (2020). "Study of Thin Layers of Cadmium Oxide (CdO) Nanostructure”, Nano Prog, 2(3), 1-10.

369.Heidari, A. (2020). "Effect of Solvent on NonLinear Synchrotron Absorption of Multi-Walled Carbon Nanotubes (MWCNTs) with DNA/RNA Function”, Sci. Int. (Lahore), 32(3), 291-315.

370.Heidari, A., Schmitt, K., Henderson, M., Besana, E. (2020). "Study of Copernicium Nanoparticles Delivery Process in Human Cancer Cells, Tissues and Tumors Under Gravitationally Accelerating Ions Through the Super Contorted 'Tubular' Polar Areas of Magnetic Fields”, Adv. Sci. Eng. Med, 12(5), 571-575.

371.Kashi, A. S. Y., Khaledi, S., \& Houshyari, M. (2016). CT simulation to evaluate of pelvic lymph node coverage in conventional radiotherapy fields based on bone and vessels landmarks in prostate cancer patients. Iranian journal of cancer prevention, 9(3).

372.Kashi, A. S. Y., Razzaghdoust, A., \& Rakhsha, A. (2017). A comparative study of treatment toxicities between FOLFOX 4 and modified FOLFOX 6 in
Iranian colorectal cancer patients. Iranian Journal of Cancer Prevention, 10(1).

373.Kashi, A. S. Y., Yazdanfar, S., Akbari, M. E., \& Rakhsha, A. (2017). Triple negative breast cancer in Iranian women: clinical profile and survival study. International Journal of Cancer Management, 10(8)

374. Yousefi Kashi, A. S., Montazeri, R., \& Rakhsha, A. (2018). Clinical Outcome and Prognostic Factors in Iranian Breast Cancer Patients After Neoadjuvant Chemotherapy: A Comparative Matched Study. International Journal of Cancer Management, 11(5).

375.Rakhsha, A., Anvari, A., Razzaghdoust, A., \& Kashi, A. S. Y. (2017). Clinical outcome and prognostic factors for very young patients with breast cancer: A comparative matched single institution study in Iran. International Journal of Cancer Management, 10(9).

376.Rakhsha, A., Kashi, A. S. Y., \& Hoseini, S. M. (2015). Evaluation of survival and treatment toxicity with high-dose-rate brachytherapy with cobalt 60 in carcinoma of cervix. Iranian Journal of Cancer Prevention, 8(4).

377.Kashi, A. S. Y., Mofid, B., Mirzaei, H. R., \& Azadeh, P. (2010). Overall survival and related prognostic factors in metastatic brain tumors treated with whole brain radiation therapy. Research Journal of Medical Sciences, 4(3), 213-216. 